\title{
Divergent impact of grazing on plant communities of created wetlands with varying hydrology and antecedent land use
}

Kimberly A. Lodge, Anna Christina Tyler*

Thomas H. Gosnell School of Life Sciences

Environmental Science Program

Rochester Institute of Technology

Rochester, NY, USA 14623

*Corresponding author Email: actsbi@rit.edu

Phone: (585) 475-5042

ORCID: 0000-0002-7845-995X

Acknowledgments: The authors gratefully acknowledge Waste Management of New York and the Thomas H. Gosnell School of Life Sciences and the College of Science at the Rochester Institute of Technology for supporting this work. We are grateful to Bruce Cady for participating in grazer monitoring, to Taylor Williams, Delanie Spangler, Kaitlyn Moranz, Elizabeth Bruen, Sonia Huang, Michael McGowan, Lisa Kratzer, Melissa Maurer Harrison, and Rachel Allen for assistance in the field, and to Nicole Fornof and Rebecca Zayatz for logistical support. 


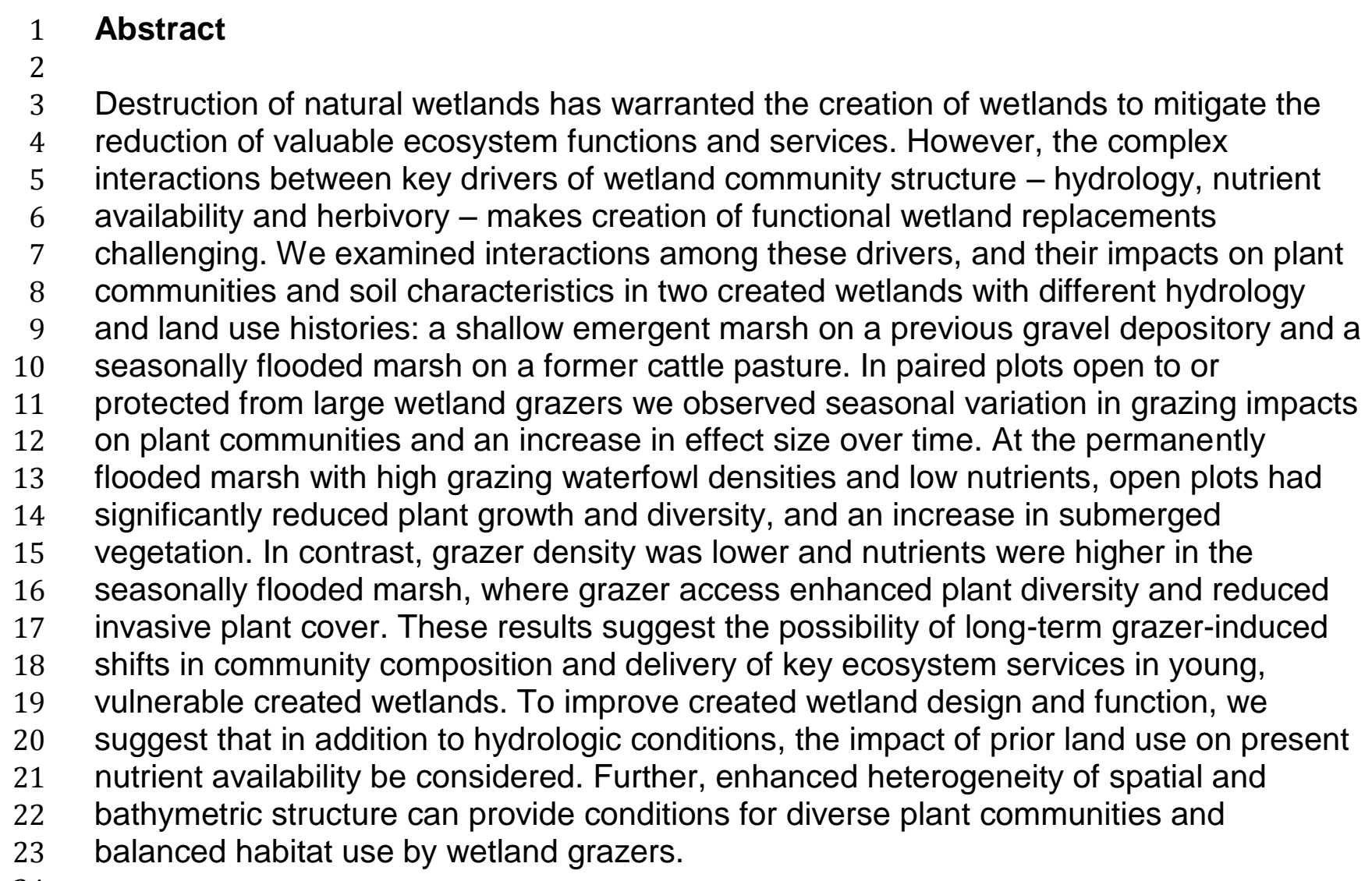

Keywords: freshwater marshes, created wetlands, grazing, biodiversity, management, hydrology; invasive plants 


\section{Introduction}

The abiotic and biotic structures and processes - transformations of matter and energy - that take place within wetland ecosystems result in the production of ecologically, economically, and culturally valuable natural resources (Costanza et al. 1997; Costanza et al. 2014; Georgiou and Turner 2012). A key aspect of wetland function and habitat provision is the presence of emergent macrophyte communities which influence biogeochemical processes and, in turn, are shaped by both biotic and abiotic factors (Rejmankova 2011; Tanner and Headley 2011; Thomaz and Cunha 2010). The primary factors that drive plant diversity and ecosystem function in natural wetlands - hydrology, nutrient availability, and herbivory - interact in complex and dynamic ways that are not fully understood, complicating the planning and design of projects related to wetland creation and restoration (Bakker et al. 2013; Bakker et al. 2016; Engels and Jensen 2010). Created wetlands are prone to colonization by invasive plants and may have lower species richness without active management and planting native species; this leads to the development of alternative community structure and successional trajectories (LePage 2011; Matthews and Spyreas 2010; Stefanik and Mitsch 2012). In order to enhance the success of wetland creation and restoration attempts, a better understanding of abiotic and biotic controls on wetland structure and function is required.

Hydrology is the ultimate driver of wetland structure and function, and variations in surface water depth and duration of saturation regulate soil and water chemistry by determining oxygen availability and soil redox status; this indirectly controls nutrient availability for competing plants and microorganisms (Jahangir et al. 2016; Song et al. 2012), and directly controls the number, type, and distribution of individual plant species (Gurnell et al. 2012; Zhang et al. 2012). The resulting plant communities provide food and habitat for wetland herbivores, such as waterfowl, which choose their habitats based on water depth and resource availability (Bino et al. 2014; Pickens and King 2014). When wetlands are created by altering hydrology of land previously used for other purposes, decisions made during the planning and construction can alter habitat 
suitability for waterfowl and other grazers, changing potential grazer influence on wetland function. The consequences of these alterations in created wetlands is important to more fully understand.

Aquatic herbivores carry out key top-down controls on community dynamics through the selection of plant species based on the nutrient content, palatability, or physical stem structure (Duarte et al. 2014; Gutbrodt et al. 2012; Morrison and Haye 2012). At high densities and intense grazing, herbivores can significantly reduce aboveand below-ground biomass of preferred plants; this drives plant competition as unpalatable species gain a competitive advantage and ultimately lead to long-term reductions in plant community diversity (Baldassarre et al. 2006; Bertness et al. 2014; He and Silliman 2016; Wood et al. 2012). Foraging behaviors also have strong implications for invasive species success in created wetlands; native plant species are often preferred by native grazers, and rapid clonal growth of invasive species prevents significant control by herbivores (Grosholz et al. 2009; Li et al. 2014). Created wetlands may be especially vulnerable to grazer-induced shifts in community composition, because their plant communities are young and less resilient than mature, natural wetlands. This vulnerability may be exacerbated by the massive increases in grazing waterfowl populations observed in recent decades (Ankney 1996).

Herbivores may also alter soil dynamics through direct disruptions to the soil layers during root or rhizome removal, and through indirect alterations to nutrient pools in the soil (Kotanen and Abraham 2013; Pulido et al. 2016). The deposition of nutrientrich feces while foraging can increase both nitrogen and phosphorus levels (Mallin et al. 2016; Telesford-Checkley et al. 2017); however, removal of nutrient-rich plant material before moving on to another area can decrease local nutrient availability (Kitchell et al. 1999; Metcalfe et al. 2014). Also, reallocation of resources by damaged plants, and increased nutrient uptake for recovery growth may lead to decreased nutrient pools and root exudation of labile carbon (Gao et al. 2008; Pineiro et al. 2010). Continued reductions in plant biomass may further decrease carbon availability by lowering litter input during senescence (Bai et al. 2012; Medina-Roldán 2012; Yan et al. 2013). This could pose further problems in the development of communities in created wetlands, 
which often have significantly lower soil organic matter than comparable natural wetlands (e.g., Campbell et al. 2002; Fennessy et al. 2008).

The impact of wetland herbivores on plant communities can be significant, but interactions with nutrient availability and hydrology likely contribute to the communitylevel response and resilience to disturbance. Resource limitation in nutrient-poor ecosystems may prevent plant regrowth after grazing; however, grazing in nutrient-rich ecosystems may actually facilitate competition and diversity (Fornoni 2011; Proulx \& Muzumder 1998). Considering the constant competition for resources between plants and microorganisms, the level of nutrients within the system becomes important to combat detrimental impacts of grazers. Unique to created wetlands is the legacy of prior land use on present nutrient availability; this link is not clearly defined, but may have cascading impacts on the ability of plant communities to recover from grazing events (Foster et al. 2003). These impacts can be especially pronounced during migration periods or at over-wintering grounds when grazer populations are at their highest and may result in limiting the re-establishment of plants in subsequent growing seasons (Chaichana et al. 2011; Guillaume et al. 2014; Bakker et al. 2018).

The overarching goal of our study was to evaluate the interactions between hydrology, nutrient availability, and herbivory in created wetlands in order to inform the design and management of similar systems before and after construction. These interactions were evaluated in two created, emergent freshwater wetlands with different prior land use histories: wet and low nutrients, dry and high nutrients. While these systems don't allow a full factorial analysis of driving forces, the contrasting nature of these systems allows a unique opportunity for comparison of the controls on wetland structure-function relationships in created wetlands. We hypothesized that:1) grazing pressure will be higher in created wetlands that are permanently flooded, and will shift seasonally in time with migration cycles, 2) the presence of grazers will decrease both plant growth and diversity, with a greater effect where grazing pressure is high, and 3) the removal of plant matter by grazing will decrease soil nutrient pools and organic matter. 
117

118

119

120

121

122

123

124

125

126

127

128

129

130

131

132

133

134

135

136

137

138

139

140

141

142

143

144

145

146

\section{Methods}

Study sites

This study was conducted from 2014 to 2016 in two created wetlands at High Acres Nature Area (HANA) in Perinton, New York, USA, both of which are owned and managed by Waste Management of New York and New England, LLC. Both wetlands were created as mitigation projects associated with a landfill expansion. Area 1 North (A1N; $43^{\circ} 05^{\prime} 33.37^{\prime \prime} \mathrm{N}, 77^{\circ} 23^{\prime} 10.34^{\prime \prime} \mathrm{W}$ ) was created in 2009 as a 1.87 ha shallow marsh. The site served as a gravel-mining depository until approximately the mid-1960s, before being abandoned and left fallow. Prior to mining, the area was used for agricultural purposes. At the time of construction and in subsequent years, native emergent species - Sagittaria latifolia, Alisma plantago-aquatica, and Polygonum spp. - were planted and were the dominant species at the start of this study. However, immediately following construction, invasive Typha latifolia and Typha angustifolia colonized the majority of the site, leading to extensive control executed via manual cutting, pulling, and herbicide applications (glyphosate) between 2010 and 2016 that significantly reduced the cover of Typha spp. Following the initiation of this study, no intentional invasive plant control was conducted in the vicinity of the treatment plots. The hydrology of $\mathrm{A} 1 \mathrm{~N}$ is driven by subsurface flow from an adjacent abandoned quarry pond and precipitation; a culvert at the southeast corner allows water control and maintenance of standing water yearround.

Area 3 (A3; $\left.43^{\circ} 05^{\prime} 16.14^{\prime \prime} \mathrm{N}, 77^{\circ} 22^{\prime} 15.06^{\prime \prime} \mathrm{W}\right)$ was a cattle pasture prior to construction of approximately 1.63 ha of shrub/scrub and shallow marsh area in 2012. Groundwater flow from an adjacent hillside and precipitation are the dominant hydrologic drivers at this site; there was no water control capacity during the study period. At the time of construction and in subsequent years, native shrub and emergent wetland species were planted throughout and Typha spp., A. plantago-aquatica, and Polygonum spp. were dominant at the initiation of this study. Typha spp. seed heads were cut each summer and plants were sprayed with herbicide (glyphosate) each fall since 2013, avoiding experimental plots. 
Characterization of grazing pressure

Abundance of large wetland herbivores was quantified from September 2015 to September 2016 by the authors and trained volunteers. We recorded the number and species of grazers present (including tracks and houses/nests), their behavior (foraging, swimming, nesting, etc.), date, and time of day, during all visits to the two wetlands. The frequency of observation varied between the two wetlands, but was sufficient to demonstrate differences in grazer identity and density between sites. Results were converted to grazer density (area calculated using ArcGIS mapping software) across seasons (spring, summer, fall, and winter; Marklund et al. 1992).

Experimental design: herbivore exclusion

In June 2014, 16 pairs of $1 \mathrm{~m}^{2}$ caged (herbivore exclusion) and uncaged control (open to herbivores) plots arranged in four blocks of four pairs, were established randomly at each site (64 total plots). Paired caged and uncaged plots were $1 \mathrm{~m}$ apart and at least $3 \mathrm{~m}$ from another pair. Caged plots were set up by wrapping galvanized

163 hardware cloth (1.27 cm mesh, $1.22 \mathrm{~m}$ tall) around four polyvinyl chloride pipes (PVC);

164 uncaged plots were marked with PVC pipes only. In May 2015, one additional three-

165 sided caged plot was established at each block to evaluate potential cage effects (8

166 total cage-control plots).

Hydrologic conditions and soil nutrient availability

Hydrologic conditions were evaluated by averaging surface water depths from 3

171 (September) of each year. Three soil cores (2.5 cm diameter $x 10 \mathrm{~cm}$ deep) were

172 extracted from each plot with an auger in September 2014, 2015, and 2016 and in May

173 2016, and subdivided for organic matter and nutrient analysis. Soil organic matter

174 content was determined using the loss on combustion method (Heiri et al. 2001).

175 Inorganic nitrogen was extracted by shaking wet soil with 2M potassium chloride 176 (Keeney and Nelson 1982). Ammonium was analyzed using the phenol-hypochlorite 
177 method and a Shimadzu 1800 spectrophotometer (Solorzano 1969). Nitrate+nitrite was

178 measured with the cadmium reduction method and a Lachat Quikchem 8500

179 autoanalyzer (Lachat 2003). Total inorganic nitrogen (TIN) was calculated by summing

180 extractable ammonium and nitrate+nitrite. Total phosphorus (TP; May and September

1812016 only) was extracted from soil samples by adding magnesium nitrate to soil dried at

$18260^{\circ} \mathrm{C}$, ashing in a $550^{\circ} \mathrm{C}$ oven for two hours, and dissolving in sulfuric acid before

183 analysis using the ammonium molybdate method (Murphy \& Riley 1962).

Plant cover, diversity and belowground biomass

Vegetation measurements were collected at three to four time points during the growing season in all plots starting in June 2014 and ending in September 2016. Percent cover of each species was estimated by at least 2 observers per plot and averaged to eliminate observer bias. Plant diversity was evaluated using species richness $(S)$ and the Shannon-Weiner Diversity Index $\left(H^{\prime}\right)$. Plant stem density and

191 height (three tallest stems of each species) were measured in May, June, July and

192 September of 2016 for all species. Belowground biomass was measured in September

193 2016. One soil core (10 cm diameter x $25 \mathrm{~cm}$ depth) was collected from each plot using 194 an auger, washed through a $1 \mathrm{~mm}$ mesh sieve to remove soil particles, dried $\left(60^{\circ} \mathrm{C}\right)$ 195 and weighed (Evers et al. 1998).

Statistical analyses

All statistical analyses were completed using JMP 13 Pro statistical software.

199 Prior to selection of statistical analysis method, each dataset was checked for normality 200 and homogeneity of variance. Grazer density was analyzed using a one-way Kruskal-

201 Wallis test to compare total average individuals per hectare between sites within 202 seasons (i.e. spring $\mathrm{A} 1 \mathrm{~N}$ vs spring $\mathrm{A} 3$, etc.).

To characterize between site differences, we made comparisons of control plots 204 only for organic matter, total inorganic nitrogen, and total phosphorus using a one-way 205 analysis of variance (ANOVA). We also used a full-factorial three-way ANOVA to 
206

207

208

209

210

211

212

213

214

215

216

217

218

219

220

221

222

223

224

225

226

227

228

229

230

231

232 Grazing Pressure

\section{Results}

\section{Hydrology} by mid-June.

compare intra-site differences between these variables with treatment (caged/uncaged), season (spring, fall), and year (2014-2016), when applicable, as fixed factors.

Statistical analyses for effects of grazing on stem height, stem density, and

percent cover for individual species were conducted only for species with a percent

cover $\geq 5 \%$ in at least five plots across the growing season. Calculation and comparison

of total plant cover and diversity indices ( $S$ and $H^{\prime}$ ) included minor species. All

Polygonum species and Typha species were grouped together for plant height

analyses. We made between site comparisons of total plant cover, $S$, and $H^{\prime}$ ' using a

one-way ANOVA, only including uncaged control plots in this analysis. Using a full

factorial three-way ANOVA we compared differences within sites for all other plant variables with treatment (caged/uncaged), season (spring, early summer, mid-summer, fall), and year (2014-2016), when applicable, as fixed factors. Invasive species cover was evaluated for $\mathrm{A} 3$ only because of the low cover (typically $<1 \%$ ) in $\mathrm{A} 1 \mathrm{~N}$ in any one season. For all variables, when significant differences were found, a Tukey's HSD post hoc analysis was used to elucidate differences among treatments.

$\mathrm{A} 1 \mathrm{~N}$ was flooded throughout the year, whereas $\mathrm{A} 3$ was seasonally flooded and was typically dry by early July. The average water depth between May and September was consistently two or more times deeper in A1N than A3 (Fig. 1). A drought in 2016 decreased average water depths in both wetlands, and resulted in $\mathrm{A} 3$ completely drying 
At both sites we observed Canada goose (Branta canadensis), ducks (Anas spp.), whitetail deer (Odocoileus virginianus), North American beaver (Castor canadensis), and the common muskrat (Ondatra zibethicus). Waterfowl comprised the majority of grazer abundance at both sites: $99-100 \%$ and $66-100 \%$ of grazers were waterfowl at $\mathrm{A} 1 \mathrm{~N}$ and $\mathrm{A} 3$, respectively. Overall grazer density was significantly greater in $\mathrm{A} 1 \mathrm{~N}$ than $\mathrm{A} 3$ (41.2 \pm 7.4 and $4.9 \pm 1.5$ individuals ha $^{-1}$, respectively; $\mathrm{X}^{2}=41.9, \mathrm{p}$ $<0.0001$; Fig. 2), but the relative difference varied across seasons. Grazer density was roughly 90 (summer) and 8 (fall, peak) times higher in $A 1 \mathrm{~N}$ than $A 3\left(X^{2}=18.2\right.$ and 26.4, respectively, $p<0.0001)$, but were similar in spring and winter $\left(x^{2}<1, p=0.95\right.$ and $x^{2}$

$242=1.3, p=0.25$, respectively).

Nutrient availability

Soil nutrients and organic matter in control plots were consistently higher in A3 relative to $\mathrm{A} 1 \mathrm{~N}$ (Table $\mathrm{S} 1$ ): organic matter content $(\mathrm{OM})$ was 1.5 times greater (13.4 \pm 0.5 versus $7.5 \pm 0.4 \% ; p<0.0001$ ); total inorganic nitrogen (TIN) was 3 times greater (17.1 \pm 3.4 versus $6.2 \pm 1.8 \mathrm{mg} / \mathrm{kg}$; $\mathrm{p}<0.0001)$; total phosphorus (TP) was 1.5 times greater (1002.7 \pm 53.2 versus $704.3 \pm 28.0 \mathrm{mg} / \mathrm{kg} ; \mathrm{p}<0.0001)$, respectively. In A1N, grazing significantly reduced soil OM (caged= $8.9 \pm 0.4 \%$, uncaged $=7.5 \pm 0.4 \%$; $p$

$251=0.046$; Table 1 and 2). This trend was similar in A3, though not significant (caged

$252=14.1 \pm 1.1$, uncaged $=13.4 \pm 1.1 \% ; p=0.54 ;$ Table 1 and 2 ). Spring flush of TIN

253 resulted in significantly higher concentrations (up to 3 times higher) in spring 2016 than

254 all fall concentrations in $\mathrm{A} 1 \mathrm{~N}$ (season $\mathrm{x}$ year $\mathrm{p}<0.0001$; Table 1 and Table 2). This trend 255 was similar in A3 in 2014 and 2015 only (season $x$ year $p=0.002$; Table 1 and 2). There 256 were no significant effects of grazing on TIN at either site, though in $\mathrm{A} 1 \mathrm{~N}$ uncaged plots 257 were slightly higher than caged plots $(6.2 \pm 1.8$ versus $4.8 \pm 0.6 \mathrm{mg} / \mathrm{kg}$, respectively; $p$ $258=0.09)$. In A1N, there were no significant effects of either season or grazing on TP 259 (Table 1 and 2); in A3, fall concentrations of TP were 1.2 times higher than spring ( $p$ $260<0.0001)$, and were negatively affected by grazing ( $p=0.02$; Table 1 and 2). 
Total plant cover was similar between $A 1 \mathrm{~N}$ and $\mathrm{A} 3$ in the control plots $(p=0.11$; Table S1). In A1N, grazing significantly reduced plant cover (Fig. 3), but a significant three-way interaction suggests that the impact of grazers varied by season and across years ( $p<0.0001$; Table 2, Fig. 4a). The greatest grazing effect occurred in mid-summer (July), the height of the growing season (caged $=112.7 \pm 6.0$, uncaged $=81.8 \pm 7.8 \%$ ). These effects increase over time, with the difference in cover between caged and uncaged plots (C-U) increasing from approximately $5 \%$ in 2014 to $55 \%$ in 2016 . In A3, a significant two-way interaction also showed similar trends of total plant cover varying by season and across different years ( $p<0.0001$; Table 2, Fig. 4b). Grazers slightly reduced plant cover in $A 3$ (caged $=61.4 \pm 6.4$, uncaged $=55.1 \pm 6.4 \% ; p=0.05$ ). There were no differences between three-sided cage-control plots and uncaged control plots at either site $(A 1 N: p=0.56 ; A 3: p=0.24)$. Belowground biomass in control plots was similar between $\mathrm{A} 1 \mathrm{~N}$ and $\mathrm{A} 3\left(260.2 \pm 28.4\right.$ and $215.3 \pm 39.1 \mathrm{~g} \mathrm{~m}^{-2}$, respectively; $\mathrm{p}$ $=0.51$; Table S1). In A1N only, grazing significantly reduced belowground biomass by $30 \%\left(A 1 \mathrm{~N}=180.1 \pm 17.7 \mathrm{~g} \mathrm{~m}^{-2}, \mathrm{~A} 3=204.7 \pm 32.5 \mathrm{~g} \mathrm{~m}^{-2} ; \mathrm{p}=0.021 ;\right.$ Table 2). 0.5 , respectively, $\mathrm{p}<0.0001 ; H^{\prime}=0.4 \pm 0.1$ and $0.9 \pm 0.1$, respectively, $\mathrm{p}<0.0001$; Table S1). In $\mathrm{A} 1 \mathrm{~N}$, the substantial reduction in diversity with grazing echoed total plant cover and increased over time for both $S$ and $H$ ' such that caged plots had 1.3 and 1.7 times higher $S$ and $H^{\prime}$, respectively than uncaged plots in 2016 ( $p=0.044$ and $p=0.003$, respectively; Table 2, Fig. 4c, 4e). Seasonal variation (peak in mid-summer) in $S$ and $H^{\prime}$ also increased over time ( $\left.S: p<0.0001 ; H^{\prime}: p=0.004\right)$.

In contrast to $A 1 \mathrm{~N}$, grazing increased plant diversity in $\mathrm{A} 3$ and this effect, again, increased over time ( $S: \mathrm{p}=0.013$; $H^{\prime}: \mathrm{p}=0.003$; Table 2, Fig. 4d, 3f); in 2016, $S$ and $H^{\prime}$ were 1.3 and 1.5 times higher in uncaged as opposed to caged plots $(S:=4.9 \pm 0.6$ and $3.8 \pm 0.6$, respectively; $H^{\prime}: 1.0 \pm 0.1$ and $0.7 \pm 0.1$, respectively). A3 also showed similar 289 seasonal variations in diversity, which increased over time $\left(S: p<0.0001 ; H^{\prime}: p=0.07\right)$. 290 Grazing reduced invasive cover in A3, but not significantly (caged =8.6 \pm 3.3 , uncaged $291=5.9 \pm 2.3 \% ; p=0.07$; Table 2, Fig. 5). Invasive cover was consistently highest in the 292 fall $(p<0.0001)$ and significantly decreased over the course of the study such that cover 
was 2.5 times higher in 2014 than in 2016 (10.3 \pm 3.4 and $4.1 \pm 1.9 \%$, respectively; $p$ $294=0.006)$.

At both sites, stem height of the most common plant species was impacted more significantly by season and grazing treatment than stem density or individual species cover, but the trends were similar for all three variables (Fig. 6; Tables S2 and S3). At $\mathrm{A} 1 \mathrm{~N}$, where emergent wetland species dominated the community, the maximum effect of grazing coincided with the peak height and reduced stem height by $60-70 \%(A$. plantago-aquatica: caged $=42.1 \pm 6.8$, uncaged $=16.6 \pm 4.1 \mathrm{~cm} ;$ Polygonum spp.: caged $=108.7 \pm 6.7$, uncaged $=29.6 \pm 8.1 \mathrm{~cm}$; treatment $x$ season $p<0.001$ and $p$ $<0.0001$, respectively; Fig. 6a, Table S2). Grazing also significantly reduced the height of $S$. latifolia, another dominant emergent species, by approximately $18 \%$, though this was not seasonally dependent (caged $=73.1 \pm 6.1$, uncaged $=60.1 \pm 5.1 \mathrm{~cm} ; p=$ 0.041). In contrast, grazing significantly increased stem height for Potamogeton amplifolius, a submerged aquatic species, by approximately $35 \%$ (caged $=11.0 \pm 0.3$, uncaged $=17.1 \pm 0.7 \mathrm{~cm} ; \mathrm{p}<0.0001)$. For other emergent species, Leersia oryzoides and Schoenoplectus tabernaemontani, the reduction in stem height was not significant (Fig. 6a, Table S2).

The plant community of A3 was characterized by a mixture of wet meadow, grasses, and emergent species. Eleocharis obtusa, L. oryzoides, and $S$.

312 tabernaemontani, three native species, were significantly taller in ungrazed plots ( $p$ $313=0.048, p=0.02, p=0.004$, respectively; Fig. 6b, Table S3). Stem height of Erechtites

314 hieracifolius, another native species, was significantly greater in grazed plots, with a 315 peak difference of $65 \%$ in fall (caged $=11.7 \pm 5.8$, uncaged $=33.5 \pm 6.2 \mathrm{~cm}$; treatment $\mathrm{x}$ 316 season $\mathrm{p}<0.001)$. Conversely, grazing reduced stem height of Phalaris arundinacea 317 and Typha spp., invasive species, though not necessarily to the same degree $(F=5.6, p$ $318=0.02$ and $F=0.9, p=0.35$ for height; Fig. 6b, Table S3). 
Restoration to a stable community structure and function varies widely across ecosystems, depending strongly on antecedent conditions and management efforts. We found strong interactions between hydrology, nutrient availability, and herbivory that drove divergent and increasingly large responses to grazer exclusion in two created wetlands. In the permanently flooded wetland, the higher waterfowl grazing pressure coupled with lower nutrient availability led to substantial shifts in cover and diversity of emergent plants, promoting submerged species and a change in soil composition. With seasonal flooding and higher nutrient availability, herbivore access was lower and greater plant diversity and to some extent reduced invasive plant cover was observed in areas exposed to grazing. This suggests long-term consequences of intense grazing for habitat provision and delivery of other desirable ecosystem services. due to extensive conservation efforts, widening of historic range limits with a changing climate, and increased agricultural land (Fox et al. 2005; Gauthier et al. 2005; Baldassarre et al. 2006). As numbers exceed limitations previously set by winter temperatures, vegetation losses up to $98 \%$ have been observed (Jefferies \& Rockwell 2002; Gauthier et al. 2005). In this study, the ability of herbivores to influence wetland community dynamics was linked to temporal and spatial shifts in hydrology. Where higher water levels and open water permitted high densities of waterfowl (site $A 1 N$ ), we

342 found a significant reduction in both aboveground plant cover across the dominant 343 species and an associated reduction in belowground biomass (Table 2, Fig. 3, 4a, 6).

344 The greatest grazing impacts were observed in plots closest to a concealed goose

345 thoroughfare between an adjacent pond and the created wetland. Spring flooding in A3

346 led to similar waterfowl abundance between sites, but with heterogeneous drying

347 waterfowl abundance decreased. Our observations do not take into account grazing by

348 larger insects, or nocturnal and crepuscular mammals, and while plant cover was

349 impacted less in A3, the impact on plant diversity suggests a more complex influence of 350 grazers on plant community structure.

$351 \quad$ Plant diversity at both sites (overall mean species richness in control plots, $A 1 \mathrm{~N}=$ $3522.2 \pm 0.3$ and A3 = $3.9 \pm 0.5)$ was similar to other created and restored wetlands in the 
353 United States (2-6 species), but quite low when compared to natural reference wetlands 354 in similar regions (10-12 species) (e.g., Brown and Bedford 1997; Campbell et al. 2002; 355 Matthews et al. 2009). Grazer selectivity may lead to the removal of palatable species, 356 lending a competitive advantage to plants with structural compounds or anti-herbivore 357 phenolic compounds (Grosholz et al. 2009; Gutbrodt et al. 2012; Harrison et al. 2017; 358 Levin et al. 2006; Morrison and Haye 2012). However, foraging effort is likely influenced 359 by and varies depending on multiple factors including, but not limited to, predation risk, 360 total food densities, and foraging location (Hagy and Kaminski 2015; Sherfy et al. 2011). 361 In $\mathrm{A} 1 \mathrm{~N}$, the substantial reduction of dominant, fast-growing species (A. plantago362 aquatica, Polygonum spp., and S. latifolia; Fig. 6a, Table S2) suggests convenience 363 rather than selectivity, and may explain the reduction in overall plant richness and 364 diversity in response to grazing (Fig. 4c, 4e). Functional group shifts are subsequently 365 reflected in the increased height, density, and cover of $P$. amplifolius, a submerged 366 species, that perhaps flourished under the greater light availability in uncaged plots where large emergent plants were removed (Mitchell 1989; Shaffer et al. 2015). Set in the different context of hydrology, nutrient availability, and grazing pressure, exclusion of grazers in A3 resulted in contrasting impacts on dominant species, suggesting dissimilar trajectories of wetland development. Grazer control resulted in neutral or positive trends in growth for many common native species, in

372 contrast to the most common invasive species at the site ( $P$. arundinacea and Typha 373 spp.) that were negatively impacted. These species also exhibited significant leaf 374 damage by vertebrates (deer clipping) and invertebrates (snail radulations) (Fig. 6b, 375 Table S3). P. arundinacea and Typha spp., typically the tallest plants by early to mid376 summer, may have protected shorter native species from herbivore access (Bagousse377 Pinguet et al. 2012; Barbosa et al. 2009). Low to moderate levels of grazing may lead to 378 balanced competition among species, promoting greater overall survivorship and 379 diversity (Hegland et al. 2013; Luo et al. 2012). These asymmetries between native and 380 non-native plants in competitive ability and susceptibility to herbivores may explain their 381 ability to coexist under moderate grazing pressure (Heard and Sax 2013). Without the 382 mediating control of grazers, invasive species cover increased and diversity decreased 
383

as native species were out-competed (Fig. $4 \mathrm{~d}, 4 \mathrm{f}, 5)$. This contrasts with the suggestion that invasive species have a competitive advantage because native grazers prefer native plants, or because invasive species contain novel chemical defenses intolerable for native grazers (Blossey \& Notzold 1995; Callaway \& Ridenour 2004). Invasive $P$. arundinacea was repeatedly introduced to North America as a forage grass for livestock, suggesting that it is both palatable and has some nutritional value and may be selectively grazed (Laverge and Molofsky 2004). The most common herbivorous waterfowl (B. canadensis and Anas spp.) observed at our two sites are generalist herbivores; their selection of plant species may be based on accessibility rather than palatability or nutritional quality. Such grazer selectivity (or lack thereof) is important to consider when seeding/planting created wetlands after construction in order to ensure persistence of desirable species.

The impact of grazer presence on overall height and dominance of plant species was greatest at the summer height of vegetation growth, though this did not correspond with the fall peak grazer abundance. Similar trends have been observed in natural aquatic systems, where high fall and overwintering waterfowl abundance has led to subsequent reductions in plant growth and distribution in the following growing season (Chaichana et al. 2011; Guillaume et al. 2014). The interaction between grazer intensity and timing, along with nutrient availability and species-specific physiologic response, determines whether specific plant species can compensate for the herbivory. In general, plants that are not limited by nutrients can compensate or respond positively to herbivory (e.g., Fornoni 2011; Proulx and Mazumder 1998). While it is challenging to directly link antecedent land use to present soil conditions and nutrient availability, gravel substrates, as found prior to restoration in $\mathrm{A} 1 \mathrm{~N}$, are often difficult to revegetate due to low nutrient-holding capacities (Hugron et al. 2011; Johnson 1987). The comparatively low soil nitrogen, phosphorus and organic matter, and low overall plant diversity at $\mathrm{A} 1 \mathrm{~N}$, a former gravel depository, even after several years, reflects these trends. In contrast, cattle deposit large quantities of nutrients into the soil through excretion of nutrient-rich feces (McGechan and Topp 2004; McGechan et al. 2008), as reflected in the substantially higher nutrients and organic matter found at A3. Grazing in 
413 the early stages of the growing season (April and May) may have less of an impact

414 because of spring nutrient flushes, allowing for neutral growth compensation by the

415 plants, when compared to periods of higher grazing intensity and lower apparent

416 nutrient availability (June-September) (Fornoni 2011; Proulx and Mazumder 1998).

417 While very high nutrient availability can lead to monocultures because some plants are

418 released from limitation (Bobbink et al. 2010; Holdredge et al. 2010), under limiting

419 conditions, herbivory may elicit different responses depending on timing of grazing

420 pressure and nutrient availability.

$421 \quad$ In some systems, invasive plant removal alone can result in rapid recovery to

422 desired structure (e.g., approximately 4 yr; Cuevos and Zalba 2010). Created wetlands

423 that are seeded and/or planted with native species can demonstrate greater diversity

424 over time, perhaps by reducing early colonization by invasive species (Balcombe et al.

425 2005; Collinge et al. 2011). However, wetland restoration projects frequently fail to

426 produce successful results even after decades, with poor soil development as the most

427 common shortcoming (Ballantine and Schneider 2009; Ballantine et al. 2014; Moreno-

428 Mateos et al. 2012). Intense grazing in nutrient-poor emergent wetlands may be

429 counter-productive to restoration efforts. Removal of aboveground material necessitates

430 reallocation of stored below-ground resources towards recovery, substantially limiting -

431 by $30 \%$ in $\mathrm{A} 1 \mathrm{~N}$ - the expansion of belowground root networks and rhizomes (Gao et al.

432 2008; Maron \& Crone 2006; Pineiro 2010). In the absence of grazing, higher plant

433 biomass both above and belowground contributes to enhanced detritus and soil organic

434 matter (Bai et al. 2012; Vaieretti et al. 2013). Failure to take into account the potentially

435 transformational impacts of grazing on the trajectory of plant community development

436 may contribute indirectly to poor soil development. Likewise, we suspect cascading

437 impacts on biogeochemical cycling and delivery of services: as grazers continue to

438 indirectly manipulate soil characteristics, wetlands become susceptible to reductions in

439 carbon sequestration and increased emissions of greenhouse gases (Kayranli et al.

440 2010; Winton \& Richardson 2016, Spangler 2019).

441 Created wetlands may, in part, be failing to meet functional and diversity

442 expectations because young plant communities are vulnerable to shifts in composition 
443 initiated by herbivores (Moreno-Mateos et al. 2012; Seymour et al. 2010; Tanentzap et

444 al. 2009), suggesting that herbivore control is necessary for plant community

445 development (Sawtschuk et al. 2010). Increasing grazer impacts over time in this study

446 suggest cumulative and interactive effects on plant communities with potential to shift

447 the functional state from emergent to submerged vegetation where water is sufficiently

448 deep, or from low to high diversity wet meadow species where it is not. As wetlands

449 face more erratic rainfall patterns and summer drought conditions due to climate

450 change, created wetlands that lack water storage capacity or control structures may be

451 increasingly at risk. The creation of bathymetric heterogeneity within wetlands to include

452 deep and shallow areas, stream rivulets, and microtopography by including distinct

453 hydrological units and water control structures in wetland design will help to balance

454 wetland use by grazer populations by providing separate areas for nesting and

455 breeding, foraging, and open water that may be used seasonally (Ma et al. 2010; Yallop

456 et al. 2004). This will also encourage the growth and development of multiple vegetation

457 communities that may differ based on water depth, and provide different resources to

458 herbivores based on varying diets, or habitat requirements and provide resilience in the

459 face of extreme grazing or environmental fluctuations. Using small-scale protective

460 enclosures to deter grazers, especially geese, initially after plantings will also help plant

461 communities develop by protecting individuals during their most vulnerable growth

462 period. Further study is required to understand these grazer-induced shifts in functional

463 state and delivery of ecosystem services, such as carbon storage and nutrient removal. 
Ankney, C. D. (1996) An embarrassment of riches: too many geese. The Journal of Wildlife Management. 60: 217-223.

Bagousse- Pinguet, L., Gross, E. M., \& Straile, D. (2012). Release from competition and protection determine the outcome of plant interactions along a grazing gradient. Oikos, 121(1), 95-101.

Bai, Y., Wu, J., Clark, C. M., Pan, Q., Zhang, L., Chen, S., ... \& Han, X. (2012). Grazing alters ecosystem functioning and $\mathrm{C}: \mathrm{N}$ : P stoichiometry of grasslands along a regional precipitation gradient. Journal of Applied Ecology, 49(6), 1204-1215.

Bakker, E. S., Sarneel, J. M., Gulati, R. D., Liu, Z., \& van Donk, E. (2013). Restoring macrophyte diversity in shallow temperate lakes: biotic versus abiotic constraints. Hydrobiologia, 710(1), 23-37.

Bakker E.S., Pagès J.F., Arthur R., Alcoverro T. (2016) Assessing the role of large herbivores in the structuring and functioning of freshwater and marine angiosperm ecosystems. Ecography (Cop) 39:162-179 . doi: 10.1111/ecog.01651

Bakker, E.S., Veen, C., ter Heerdt, G., Huig, N., \& Sarneel, J. (2018). High grazing pressure of geese threatens conservation and restoration of reed belts. Frontiers in Plant Science 9:1649.

Balcombe, C. K., Anderson, J. T., Fortney, R. H., Rentch, J. S., Grafton, W. N., \& Kordek, W. S. (2005). A comparison of plant communities in mitigation and reference wetlands in the mid-Appalachians. Wetlands, 25(1), 130-142.

Baldassarre, G. A. Bolen, E. G., and Saunders, A. (2006). Influence of migrant tundra swans (Cygnus columbianus) and Canada geese (Branta canadensis) on aquatic vegetation at Long Point, Lake Erie, Ontario. Hydrobiologia. 567:195-211.

Ballantine, K., \& Schneider, R. (2009). Fifty- five years of soil development in restored freshwater depressional wetlands. Ecological Applications, 19(6), 1467-1480.

Ballantine, K. A., Groffman, P. M., Lehmann, J., \& Schneider, R. L. (2014). Stimulating nitrate removal processes of restored wetlands. Environmental Science and Technology, 48, 7365-7373. doi:10.1021/es500799v

Barbosa, P., Hines, J., Kaplan, I., Martinson, H., Szczepaniec, A., \& Szendrei, Z. (2009). Associational resistance and associational susceptibility: having right or wrong neighbors. annual review of ecology, evolution, and systematics, 40, 1-20.

Bertness, M. D., Brisson, C. P., Coverdale, T. C., Bevil, M. C., Crotty, S. M., \& Suglia, E. R. (2014). Experimental predator removal causes rapid salt marsh die- off. Ecology letters, 17(7), 830-835.

Bino, G., Steinfeld, C., \& Kingsford, R. T. (2014). Maximizing colonial waterbirds' breeding events using identified ecological thresholds and environmental flow management. Ecological Applications, 24(1), 142-157.

Bobbink, R., Hicks, K., Galloway, J., Spranger, T., Alkemade, R., Ashmore, M., ... \& Emmett, B. (2010). Global assessment of nitrogen deposition effects on terrestrial plant diversity: a synthesis. Ecological applications, 20(1), 30-59. 
Brown, S. C., \& Bedford, B. L. (1997). Restoration of wetland vegetation with transplanted wetland soil: an experimental study. Wetlands, 17(3), 424-437.

Campbell, D. A., Cole, A., \& Brooks, R. P. (2002). A comparison of created and natural wetlands in Pennsylvania, USA Deborah. Ecology and Management, 10, 41-49. doi:10.1023/A

Chaichana, R., Leah, R., \& Moss, B. (2011). Seasonal impact of waterfowl on communities of macrophytes in a shallow lake. Aquatic Botany, 95(1), 39-44.

Collinge, S. K., Ray, C., \& Gerhardt, F. (2011). Long- term dynamics of biotic and abiotic resistance to exotic species invasion in restored vernal pool plant communities. Ecological Applications, 21(6), 2105-2118.

Costanza, R., de Groot, R., Sutton, P., van der Ploeg, S., Anderson, S. J., Kubiszewski, I., ... Turner, R. K. (2014). Changes in the global value of ecosystem services. Global Environmental Change, 26, 152-158.

Cuevas, Y. A., \& Zalba, S. M. (2010). Recovery of native grasslands after removing invasive pines. Restoration Ecology, 18(5), 711-719.

Duarte, C., Acuña, K., Navarro, J. M., Gómez, I., Jaramillo, E., \& Quijón, P. (2014). Variable feeding behavior in Orchestoidea tuberculata (Nicolet 1849): exploring the relative importance of macroalgal traits. Journal of Sea Research, 87, 1-7.

Engels, J. G., \& Jensen, K. (2010). Role of biotic interactions and physical factors in determining the distribution of marsh species along an estuarine salinity gradient. Oikos, 119(4), 679-685.

Evers, D. A., Sasser, C. E., Gosselink, J. G., Fuller, D. A., \& Visser, J. M. (1998). The Impact of Vertebrate Herbivores on Wetland Vegetation in Atchafalaya Bay, Louisiana. Estuaries, 21(1), 1-13.

Fennessy, M. S., Rokosch, A., \& Mack, J. J. (2008). Patterns of plant decomposition and nutrient cycling in natural and created wetlands. Wetlands, 28(2), 300-310. doi:10.1672/06-97.1

Fornoni, J. (2011). Ecological and evolutionary implications of plant tolerance to herbivory. Functional Ecology, 25(2), 399-407.

Foster, D., Swanson, F., Aber, J., Burke, I., Brokaw, N., Tilman, D., \& Knapp, A. (2003). The importance of land-use legacies to ecology and conservation. BioScience, 53(1), 77-88.

Fox, A. D., Madsen, J., Boyd, H., Kuijken, E., Norriss, D. W., Tombre, I. M., \& Stroud, D. A. (2005). Effects of agricultural change on abundance, fitness components and distribution of two arctic- nesting goose populations. Global Change Biology, 11(6), 881-893.

Gao, Y. Z., Giese, M., Lin, S., Sattelmacher, B., Zhao, Y., \& Brueck, H. (2008). Belowground net primary productivity and biomass allocation of a grassland in Inner Mongolia is affected by grazing intensity. Plant and Soil, 307, 41-50.

Gauthier, G., Giroux, J. F., Reed, A., Bechet, A., \& Belanger, L. (2005). Interactions between land use, habitat use, and population increase in greater snow geese: what are the consequences for natural wetlands?.Global change biology, 11(6), 856-868.

Georgiou, S., \& Turner, R. K. (2012). Valuing ecosystem services: the case of multifunctional wetlands. Routledge. 
Grosholz, E. D., Levin, L. A., Tyler, A. C., \& Neira, C. (2009). Changes in Community Structure and Ecosystem Function Following Spartina alterniflora Invasion of Pacific Estuaries. In: Silliman, B. R., Grosholtz, E. D. and Bertness, M. D., eds. Human Impacts on Salt Marshes: A Global Perspective (pp. 23-40). Berkley, CA: University of California Press.

Guillaume, G., Matthieu, G., du Rau Pierre, D., \& Patrick, G. (2014). Effects of mute swans on wetlands: a synthesis. Hydrobiologia, 723(1), 195-204.

Gurnell, A. M., Bertoldi, W., \& Corenblit, D. (2012). Changing river channels: The roles of hydrological processes, plants and pioneer fluvial landforms in humid temperate, mixed load, gravel bed rivers. Earth-Science Reviews, 111(1-2), 129-141.

Gutbrodt, B., Dorn, S., Unsicker, S. B., \& Mody, K. (2012). Species-specific responses of herbivores to within-plant and environmentally mediated between-plant variability in plant chemistry. Chemoecology, 22(2), 101-111.

HACH Company (2014). User Manuel: ORP/Redox Probe. Loveland, CO.

Hagy, H. M., \& Kaminski, R. M. (2015). Determination of foraging thresholds and effects of application on energetic carrying capacity for waterfowl. PloS one, 10(3), e0118349.

He, Q., \& Silliman, B. R. (2016). Consumer control as a common driver of coastal vegetation worldwide. Ecological Monographs, 86(3), 278-294.

Heard, M. J., \& Sax, D. F. (2013). Coexistence between native and exotic species is facilitated by asymmetries in competitive ability and susceptibility to herbivores. Ecology Letters, 16(2), 206-213.

Hegland, S. J., Lilleeng, M. S., \& Moe, S. R. (2013). Old-growth forest floor richness increases with red deer herbivory intensity. Forest Ecology and Management, 310, 267-274.

Heiri, O., Lotter, A. F., \& Lemcke, G. (2001). Loss on ignition as a method for estimating organic and carbonate content in sediments: reproducibility and comparability of results. Journal of paleolimnology, 25(1), 101-110.

Holdredge, C., Bertness, M. D., Von Wettberg, E., \& Silliman, B. R. (2010). Nutrient enrichment enhances hidden differences in phenotype to drive a cryptic plant invasion. Oikos, 119(11), 1776-1784.

Hugron, S., Andersen, R., Poulin, M., \& Rochefort, L. (2011). Natural plant colonization of borrow pits in boreal forest highlands of eastern Canada. Botany, 89(7), 451-465.

Jahangir, M. M. R., Richards, K. G., Healy, M. G., Gill, L., Müller, C., Johnston, P., \& Fenton, O. (2016). Carbon and nitrogen dynamics and greenhouse gas emissions in constructed wetlands treating wastewater: a review. Hydrology and Earth System Sciences, 20(1), 109.

Jefferies, R. L., \& Rockwell, R. F. (2002). Foraging geese, vegetation loss and soil degradation in an Arctic salt marsh. Applied Vegetation Science, 5(1), 7-16. doi:10.1658/1402-2001(2002)005[0007:FGVLAS]2.0.CO;2

Johnson, L. A. (1987). Management of northern gravel sites for successful reclamation: a review. Arctic and Alpine Research, 530-536. 
Kayranli, B., Scholz, M., Mustafa, A., \& Hedmark, A. (2010). Carbon Storage and Fluxes within Freshwater Wetlands: a Critical Review. Wetlands, 30, 111-124. doi $=10.1 \cdot 1 \cdot 469.9380 \&$ rep $=$ rep $1 \&$ type $=$ pdf

Kitchell, J. F., Schindler, D. E., Herwig, B. R., Post, D. M., Olson, M. H., \& Oldham, M. (1999). Nutrient cycling at the landscape scale: The role of diel foraging migrations by geese at the Bosque del Apache National Wildlife Refuge, New Mexico. Limnology and Oceanography, 44(Wobeser 1981), 828-836. doi:10.4319/lo.1999.44.3_part_2.0828

Kotanen, P. M., \& Abraham, K. F. (2013). Decadal changes in vegetation of a subarctic salt marsh used by lesser snow and Canada geese. Plant Ecology, 214(3), 409-422. Lachat Instruments (2003). Determination of Ammonium, Nitrate, Ortho-phosphate and Total Phosphorus. Loveland, CO.

Lavergne, S., \& Molofsky, J. (2004). Reed canary grass (Phalaris arundinacea) as a biological model in the study of plant invasions. Critical Reviews in Plant Sciences, 23(5), 415-429.

Li, Z., Wang, W., \& Zhang, Y. (2014). Recruitment and herbivory affect spread of invasive Spartina alterniflora in China. Ecology, 95(7), 1972-1980.

LePage, B. A. (2011). Wetlands: a multidisciplinary perspective. In Wetlands (pp. 3-25). Springer, Dordrecht.

Levin, L. A., Neira, C., \& Grosholz, E. D. (2006). Invasive cordgrass modifies wetland trophic function. Ecology, 87(2), 419-432.

Luo, G., Han, Q., Zhou, D., Li, L., Chen, X., Li, Y., ... \& Li, B. L. (2012). Moderate grazing can promote aboveground primary production of grassland under water stress. Ecological Complexity, 11, 126-136.

Ma, Z., Cai, Y., Li, B., \& Chen, J. (2010). Managing wetland habitats for waterbirds: an international perspective. Wetlands, 30(1), 15-27.

Mallin, M. A., Mclver, M. R., Wambach, E. J., \& Robuck, A. R. (2016). Algal blooms, circulators, waterfowl, and eutrophic Greenfield Lake, North Carolina. Lake and Reservoir Management, 32(2), 168-181.

Maron, J. L., \& Crone, E. (2006). Herbivory: effects on plant abundance, distribution and population growth. Proceedings of the Royal Society of London B: Biological Sciences, 273(1601), 2575-2584.

Matthews, J. W., Spyreas, G., \& Endress, A. G. (2009). Trajectories of vegetationbased indicators used to assess wetland restoration progress. Ecological Applications, 19(8), 2093-2107.

Matthews, J. W., \& Spyreas, G. (2010). Convergence and divergence in plant community trajectories as a framework for monitoring wetland restoration progress. Journal of Applied Ecology, 47(5), 1128-1136.

McGechan, M. B., \& Topp, C. F. E. (2004). Modelling environmental impacts of deposition of excreted nitrogen by grazing dairy cows. Agriculture, ecosystems \& environment, 103(1), 149-164.

McGechan, M. B., Lewis, D. R., \& Vinten, A. J. A. (2008). A river water pollution model for assessment of best management practices for livestock farming. Biosystems Engineering, 99(2), 292-303. 
Medina-Roldán, E., Paz-Ferreiro, J., \& Bardgett, R. D. (2012). Grazing exclusion affects soil and plant communities, but has no impact on soil carbon storage in an upland grassland. Agriculture, Ecosystems \& Environment, 149, 118-123.

Metcalfe, D. B., Asner, G. P., Martin, R. E., Silva Espejo, J. E., Huasco, W. H., Farfán Amézquita, F. F., ... \& Quispe, H. (2014). Herbivory makes major contributions to ecosystem carbon and nutrient cycling in tropical forests. Ecology letters, 17(3), 324332.

Mitchell, S. F. (1989). Primary production in a shallow eutrophic lake dominated alternately by phytoplankton and by submerged macrophytes. Aquatic Botany, 33(12), 101-110.

Moreno-Mateos, D., Power, M. E., Comín, F. a., \& Yockteng, R. (2012). Structural and Functional Loss in Restored Wetland Ecosystems. PLoS Biology, 10(1), e1001247. doi:10.1371/journal.pbio.1001247

Morrison, W. E., \& Hay, M. E. (2012). Are lower- latitude plants better defended? Palatability of freshwater macrophytes. Ecology, 93(1), 65-74.

Murphy, J. A. M. E. S., \& Riley, J. (1962). A modified single solution method for the determination of phosphate in natural waters. Analytica chimica acta, 27, 31-36.

Pickens, B. A., \& King, S. L. (2014). Multiscale habitat selection of wetland birds in the northern Gulf Coast. Estuaries and coasts, 37(5), 1301-1311.

Piñeiro, G., Paruelo, J. M., Oesterheld, M., \& Jobbágy, E. G. (2010). Pathways of grazing effects on soil organic carbon and nitrogen. Rangeland Ecology \& Management, 63(1), 109-119.

Proulx, M., \& Mazumder, A. (1998). Reversal of Grazing Impact on Plant Species Richness in Nutrient-Poor vs. Nutrient-Rich Ecosystems. Ecology, 79(8), 25812592.

Pulido, M., Schnabel, S., Lavado Contador, J. F., Lozano- Parra, J., \& González, F. (2016). The impact of heavy grazing on soil quality and pasture production in rangelands of SW Spain. Land Degradation \& Development, 29(2), 219-230.

Rejmankova, E. (2011). The role of macrophytes in wetland ecosystems. Journal of Ecology and Environment, 34(4), 333-345.

Sawtschuk, J., Bioret, F., \& Gallet, S. (2010). Spontaneous Succession as a Restoration Tool for Maritime Cliff- top Vegetation in Brittany, France. Restoration ecology, 18(s2), 273-283.

Shaffer, G. P., Day, J. W., Hunter, R. G., Lane, R. R., Lundberg, C. J., Wood, W. B., ... \& Kandalepas, D. (2015). System response, nutria herbivory, and vegetation recovery of a wetland receiving secondarily-treated effluent in coastal Louisiana. Ecological Engineering, 79, 120-131.

Sherfy, M. H., Anteau, M. J., \& Bishop, A. A. (2011). Agricultural practices and residual corn during spring crane and waterfowl migration in Nebraska. Journal of Wildlife Management, 75(5), 995-1003.

Solorzano, L. (1969). Determination of ammonia in natural waters by the phenolhypochlorite method 11. This research was fully supported by US Atomic Energy Commission Contract No. ATS (11- 1) GEN 10, PA 20. Limnology and oceanography, 14(5), 799-801. 
Song, K., Kang, H., Zhang, L., \& Mitsch, W. J. (2012). Seasonal and spatial variations of denitrification and denitrifying bacterial community structure in created riverine wetlands. Ecological Engineering, 38(1), 130-134.

Spangler, D. S. (2019). Effects of grazer exclusion on carbon cycling in created freshwater wetlands. MS Thesis. Rochester Institute of Technology.

Stefanik, K. C., \& Mitsch, W. J. (2012). Structural and functional vegetation development in created and restored wetland mitigation banks of different ages. Ecological Engineering, 39, 104-112.

Tanentzap, A. J., Burrows, L. E., Lee, W. G., Nugent, G., Maxwell, J. M., \& Coomes, D. A. (2009). Landscape- level vegetation recovery from herbivory: progress after four decades of invasive red deer control. Journal of Applied Ecology, 46(5), 1064-1072.

Tanner, C. C., \& Headley, T. R. (2011). Components of floating emergent macrophyte treatment wetlands influencing removal of stormwater pollutants. Ecological Engineering, 37(3), 474-486.

Telesford-Checkley, J. M., Mora, M. A., Grant, W. E., Boellstorff, D. E., \& Provin, T. L. (2017). Estimating the contribution of nitrogen and phosphorus to waterbodies by colonial nesting waterbirds. Science of the Total Environment, 574, 1335-1344.

Thomaz, S. M., \& Cunha, E. R. D. (2010). The role of macrophytes in habitat structuring in aquatic ecosystems: methods of measurement, causes and consequences on animal assemblages' composition and biodiversity. Acta Limnologica Brasiliensia, 22(2), 218-236.

Vaieretti, M. V., Cingolani, A. M., Harguindeguy, N. P., \& Cabido, M. (2013). Effects of differential grazing on decomposition rate and nitrogen availability in a productive mountain grassland. Plant and soil, 371(1-2), 675-691.

Winton, R. S., \& Richardson, C. J. (2016). Top- down control of methane emission and nitrogen cycling by waterfowl. Ecology.

Wood, K. A., Stillman, R. A., Clarke, R. T., Daunt, F., \& O'Hare, M. T. (2012). The impact of waterfowl herbivory on plant standing crop: a meta-analysis. Hydrobiologia, 686(1), 157-167.

Yallop, M. L., O'Connell, M. J., \& Bullock, R. (2004). Waterbird herbivory on a newly created wetland complex: potential implications for site management and habitat creation. Wetlands Ecology and Management, 12(5), 395-408.

Yan, L., Zhou, G., \& Zhang, F. (2013). Effects of different grazing intensities on grassland production in China: a meta-analysis. PloS one, 8(12), e81466.

Zhang, L., Yin, J., Jiang, Y., \& Wang, H. (2012). Relationship between the hydrological conditions and the distribution of vegetation communities within the Poyang Lake National Nature Reserve, China. Ecological Informatics, 11, 65-75. 


\section{Figure Captions}

Fig. 1 Boxplots of water depth across the growing season (May-September) in Area 1 North (gray) and Area 3 (white) from 2014-2016. New York State experienced a drought beginning in June 2016.

Fig. 2 Mean \pm SE large grazer density observed at Area 1 North (gray) and Area 3 (white) wetlands between September 2015 and September 2016 (spring = March-May, summer $=$ June-Aug, fall $=$ Sept-Nov, winter $=$ Dec-Feb). Text values on bars are the number of individual observations per season. * indicates significant difference between sites within a season $(p<0.0001)$.

Fig. 3 (a) uncaged control plot, (b) caged grazer exclusion plot and (c) three-sided cage-control plot during summer 2016.

Fig. 4 Mean \pm SE plant characteristics measured in caged (black circle), uncaged (white square), and cage control (striped diamond) plots in study wetlands during the growing seasons of 2014-2016. Panels: (a) A1N, total plant cover (b) A3, total plant cover; (c) A1N, species richness; (d) A3, species richness; (e) A1N, Shannon-Weiner diversity scores; (f) A3, Shannon Weiner diversity scores. Note that total cover may exceed $100 \%$ when plant canopies of individual species overlap.

Fig. 5 Mean \pm SE invasive plant cover in caged (black circle) and uncaged (white square) plots in A3 wetland during the growing seasons of 2014-2016.

Fig. 6 Mean \pm SE difference in stem height (caged minus uncaged) of major species in $\mathrm{A} 1 \mathrm{~N}$ (a) and A3 (b) throughout the 2016 growing season. Positive values indicate caged > uncaged; negative values indicate uncaged $>$ caged. For species where a value of 0 is indicated, caged = uncaged stem height and where n.p. is indicated, the species was not present in either plot. " grazing treatment $p<0.05$, ** season $x$ grazing $p$ $<0.05$ based on two-way analysis of variance. 


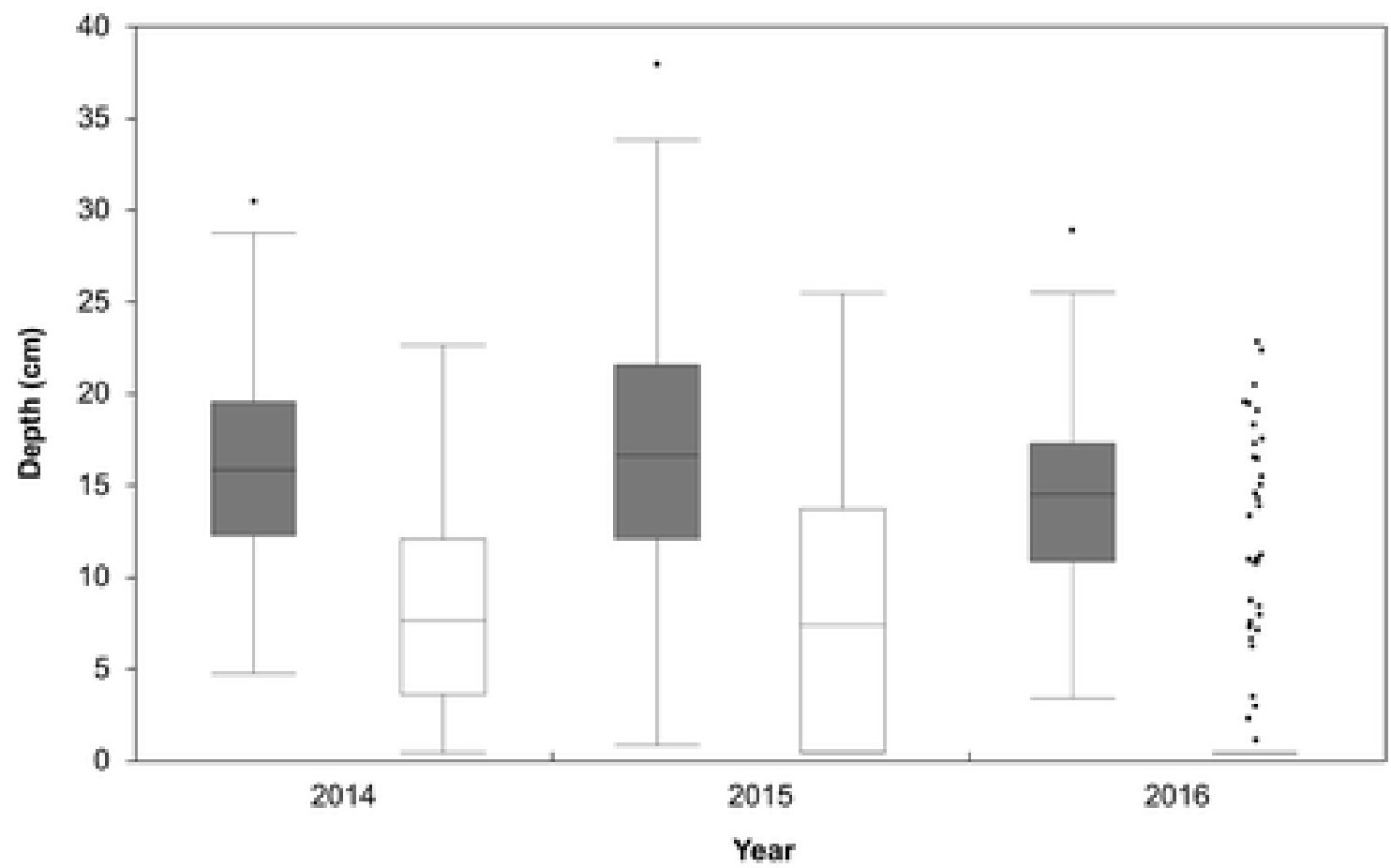

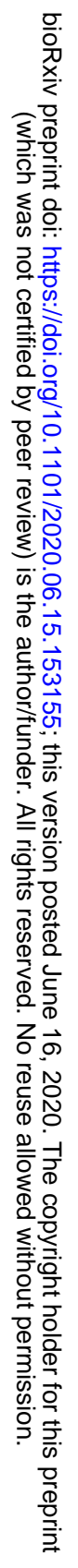




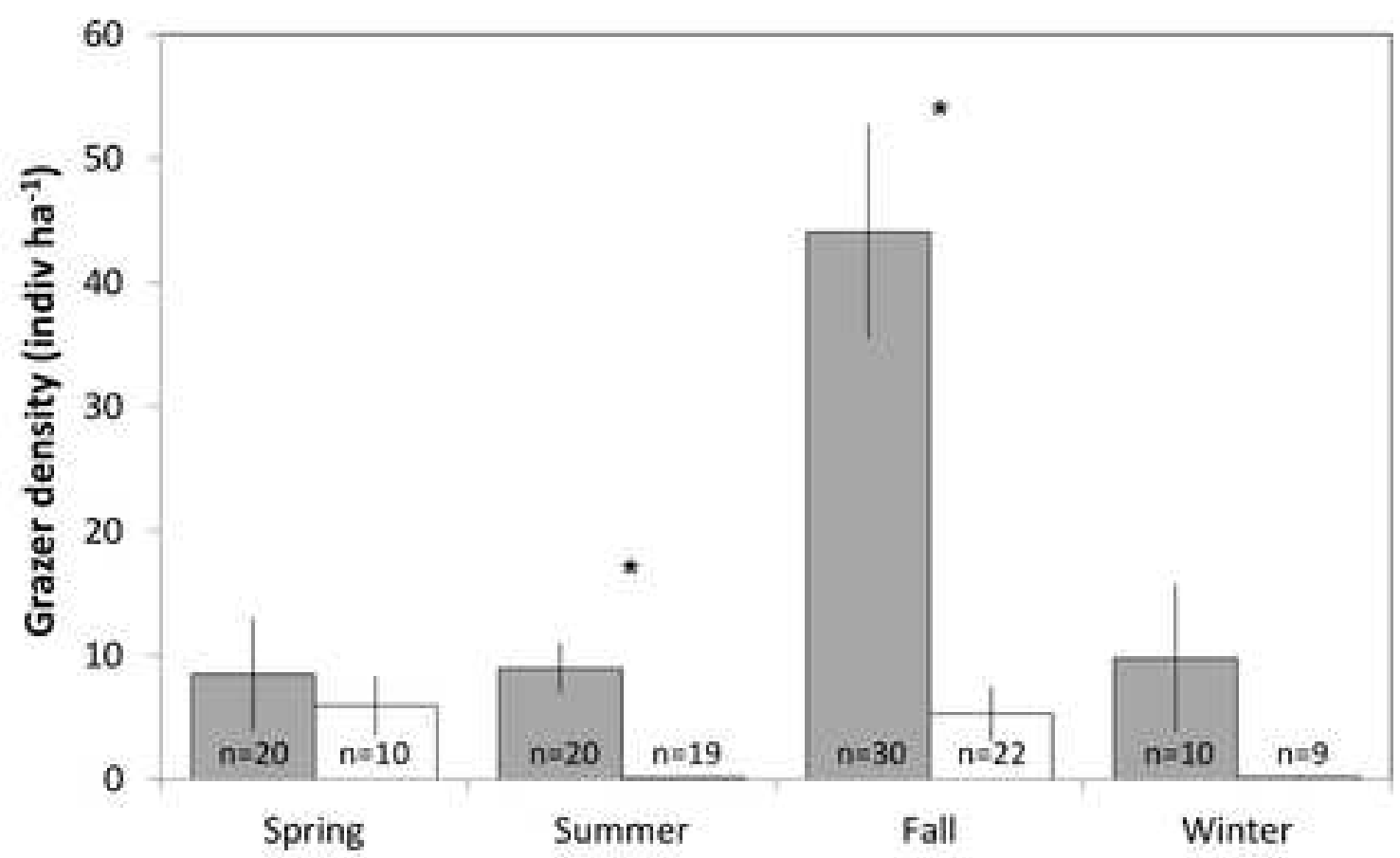

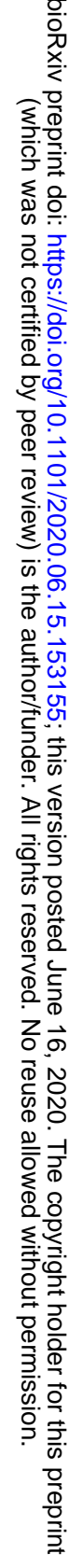



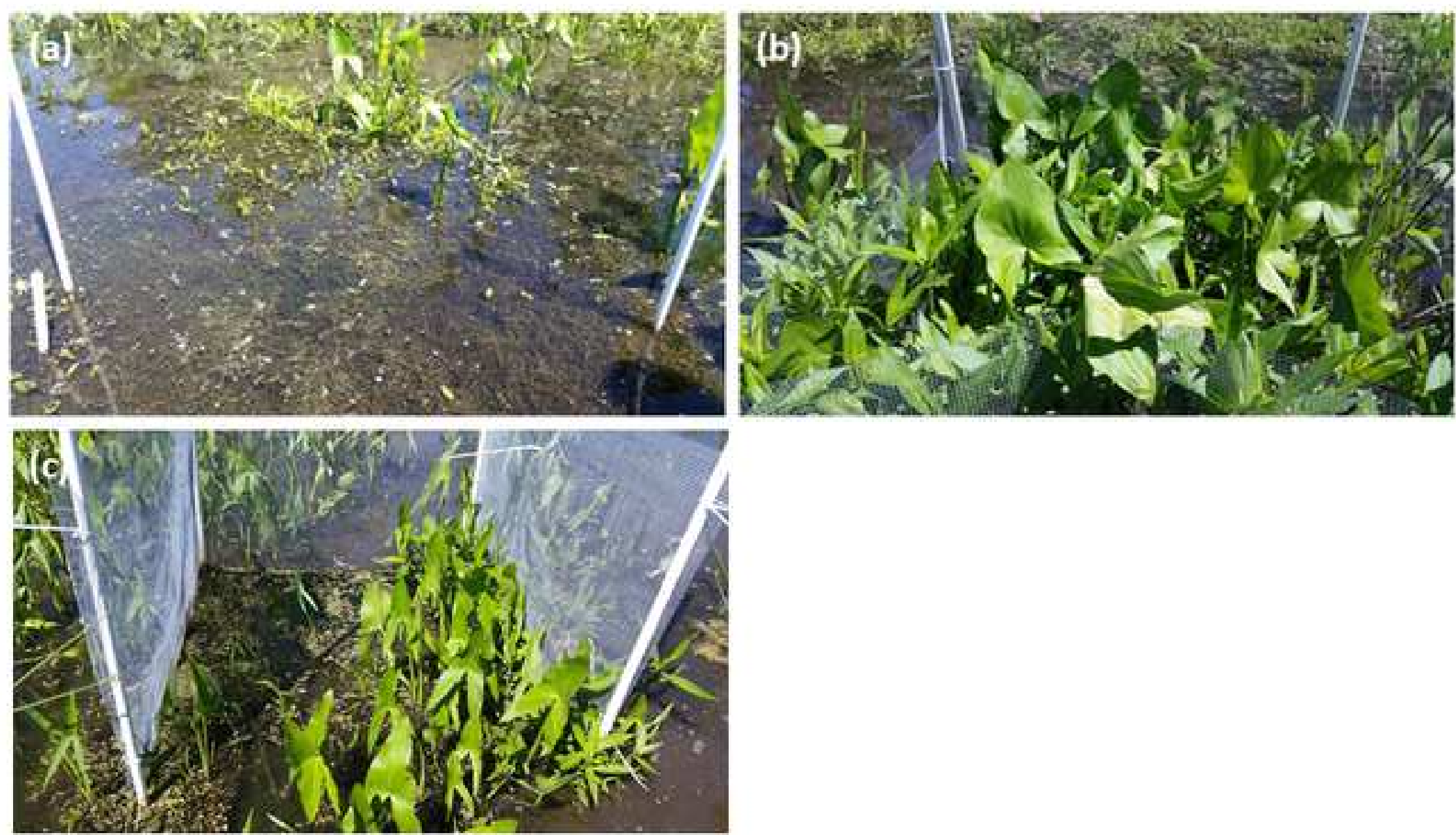

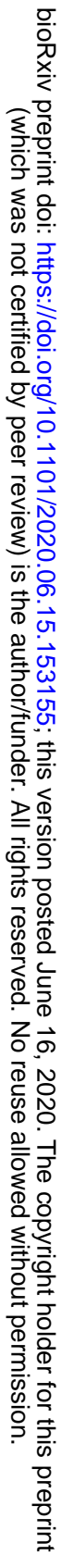




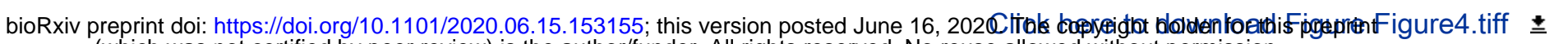
(which was not certified by peer review) is the author/funder. All rights reserved. No reuse allowed without permission.
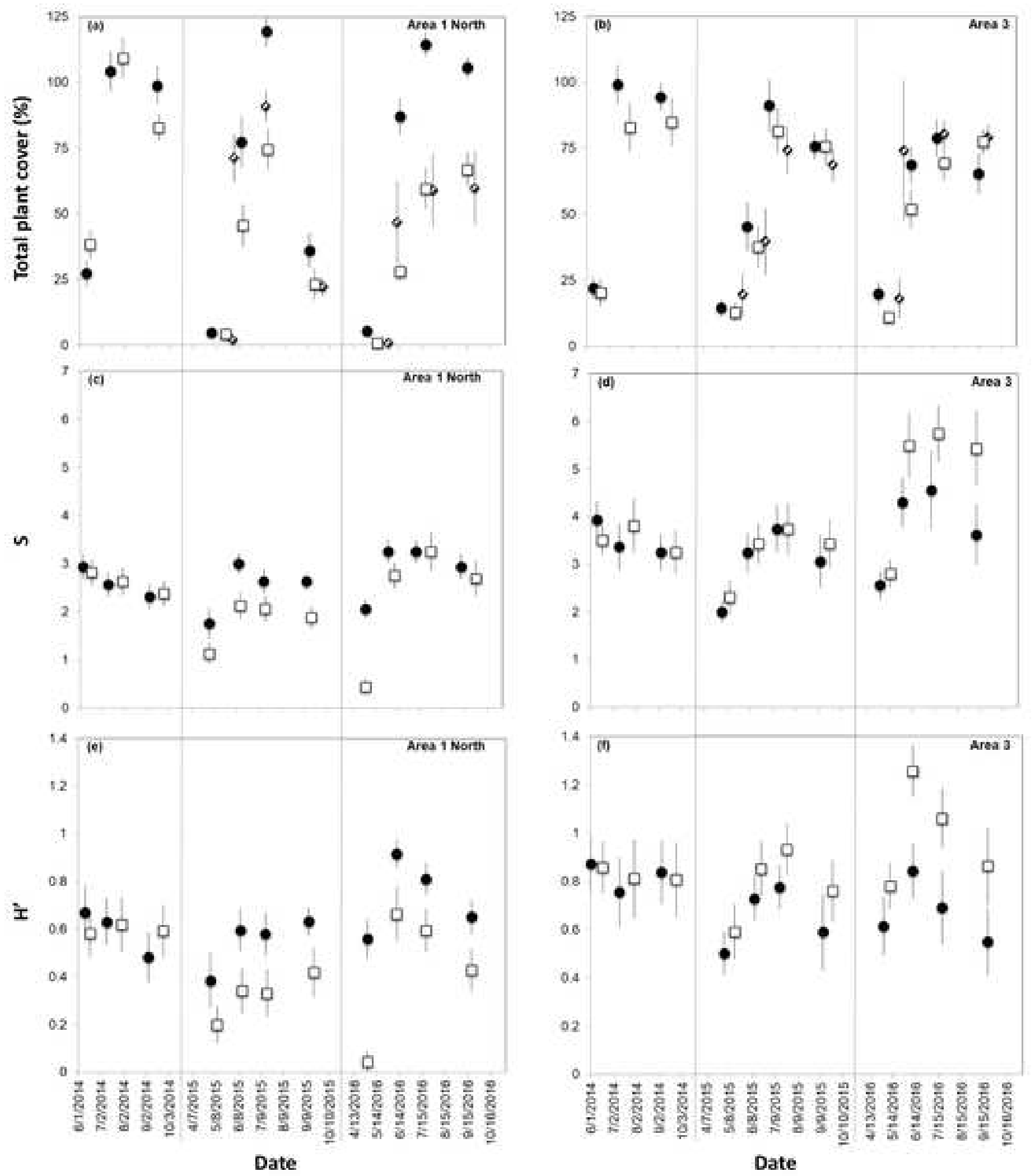

Date

Date 


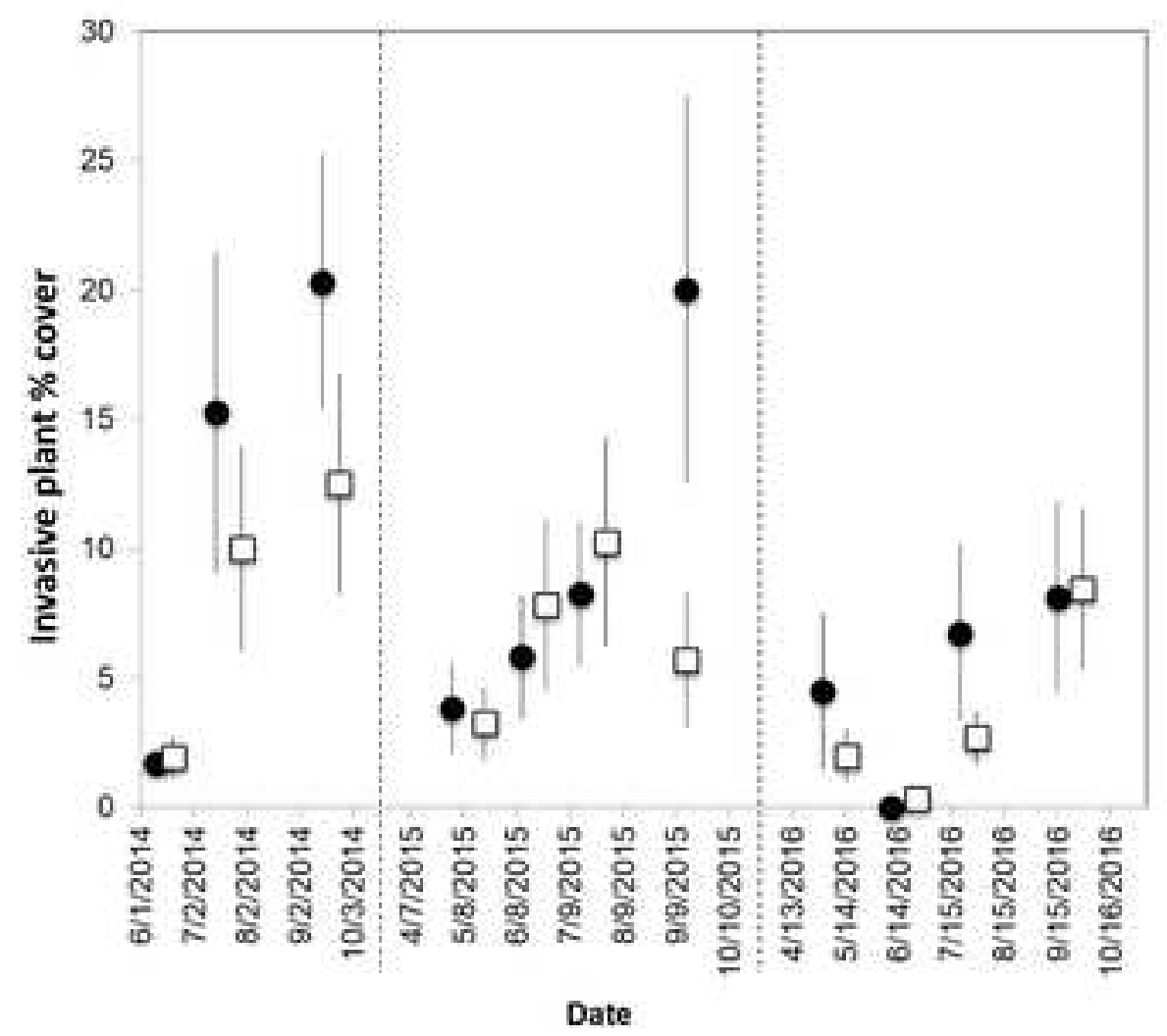

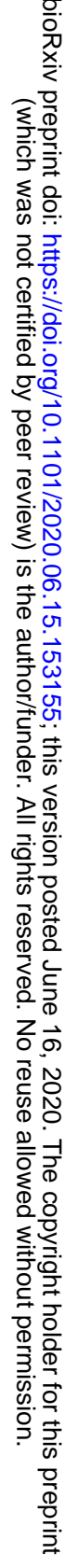


(a)

difference in stem height $(\mathrm{cm})$

(b)

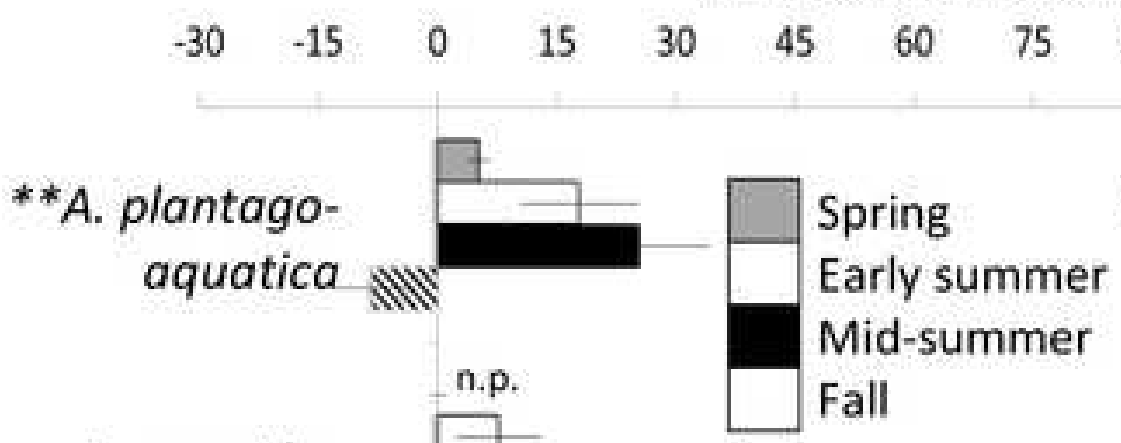

A. plantago-aquatica

$\begin{array}{llllll}-30 & -15 & 0 & 15 & 30 & 45\end{array}$

L. oryzoides

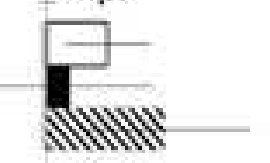
90

go-aquatica . Carex spp. $\stackrel{3}{7}$

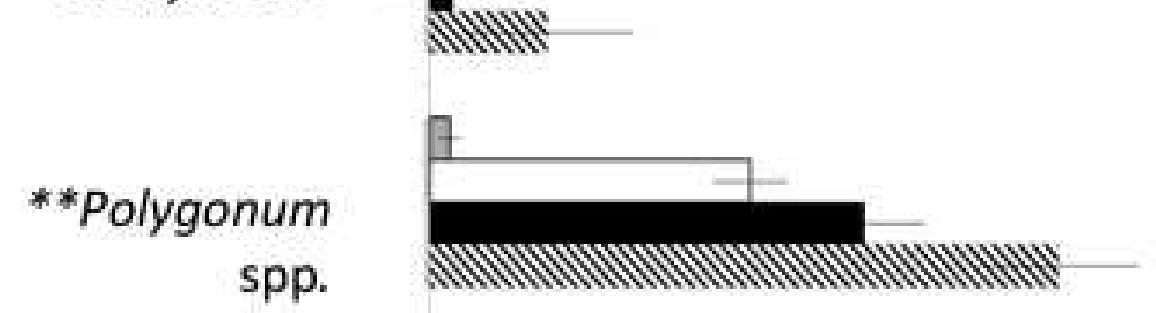
${ }^{*}$ E. obtuse
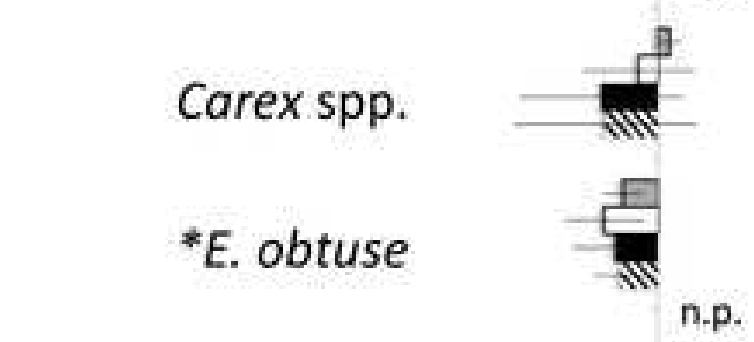

${ }^{* *}$ E. hieracifolius
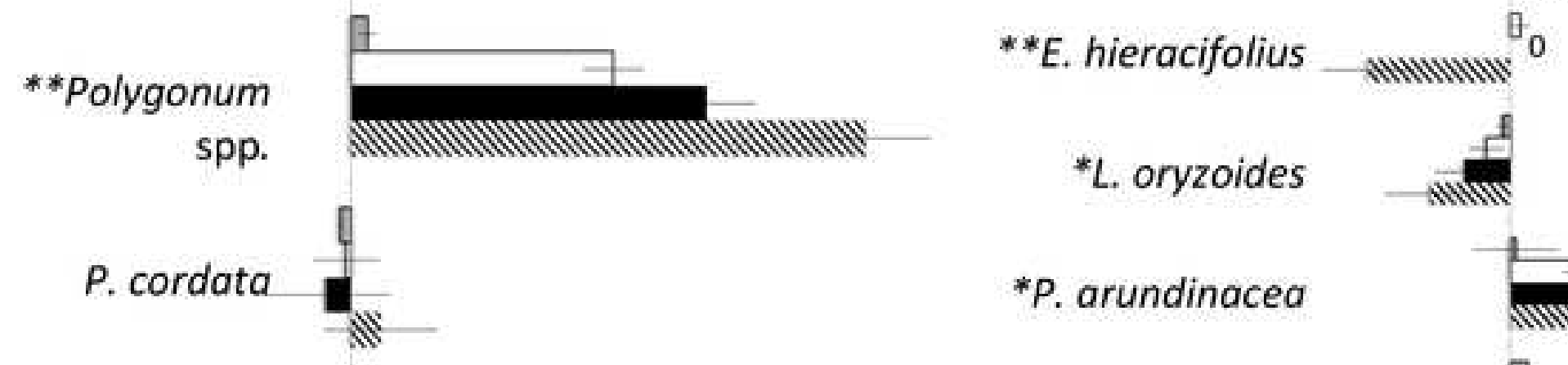

*L. oryzoides

*P. arundinacea

*P. amplifolius $f_{0}^{0}$

Polygonum spp.
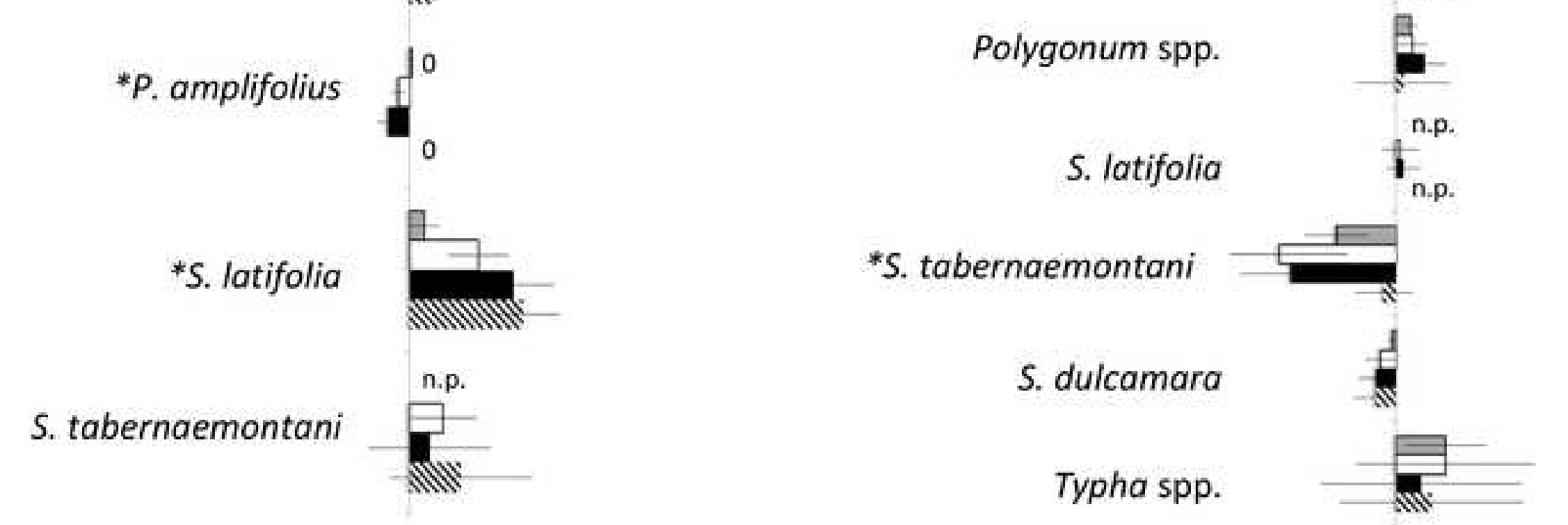

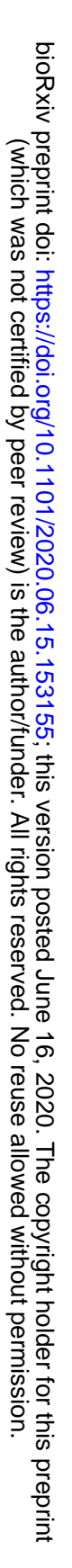


Table 1: Avg \pm SE soil characteristics measured in $A 1 \mathrm{~N}$ and $\mathrm{A} 3$, throughout the study period. $\mathrm{C}=$ caged plots, $\mathrm{U}=$ uncaged control plots.

\begin{tabular}{|c|c|c|c|c|c|c|c|c|}
\hline \multirow[t]{3}{*}{ Factor } & \multirow{2}{*}{\multicolumn{2}{|c|}{ Fall 2014}} & \multirow{2}{*}{\multicolumn{2}{|c|}{ Fall 2015}} & & & & \\
\hline & & & & & \multicolumn{2}{|c|}{ Spring 2016} & \multicolumn{2}{|c|}{ Fall 2016} \\
\hline & C & $U$ & C & U & C & U & C & U \\
\hline \multicolumn{9}{|l|}{$A 1 N$} \\
\hline Organic matter (\%) & $8.3 \pm 0.9$ & $6.9 \pm 0.7$ & $9.0 \pm 1.0$ & $7.2 \pm 0.7$ & $8.8 \pm 0.5$ & $7.2 \pm 0.4$ & $9.3 \pm 1.0$ & $8.6 \pm 1.0$ \\
\hline Total inorganic nitrogen $(\mathrm{mg} / \mathrm{kg})$ & $4.0 \pm 0.6$ & $7.1 \pm 3.5$ & $1.5 \pm 0.3$ & $2.0 \pm 0.5$ & $11.3 \pm 1.1$ & $10.5 \pm 1.1$ & $2.4 \pm 0.3$ & $5.1 \pm 1.9$ \\
\hline Total phosphorus (mg/kg) & --- & --- & --- & --- & $744.6 \pm 23.5$ & $683.7 \pm 29.7$ & $696.8 \pm 22.3$ & $724.9 \pm 26.2$ \\
\hline \multicolumn{9}{|l|}{ A3 } \\
\hline Organic matter (\%) & $13.0 \pm 0.9$ & $12.5 \pm 1.0$ & $13.4 \pm 1.1$ & $12.5 \pm 1.0$ & $15.8 \pm 1.2$ & $14.6 \pm 1.2$ & $14.1 \pm 1.0$ & $13.8 \pm 1.0$ \\
\hline Total inorganic nitrogen $(\mathrm{mg} / \mathrm{kg})$ & $15.4 \pm 5.1$ & $15.1 \pm 3.3$ & $2.6 \pm 0.4$ & $7.9 \pm 3.7$ & $25.6 \pm 3.0$ & $28.2 \pm 5.4$ & $12.9 \pm 1.7$ & $12.0 \pm 1.4$ \\
\hline Total phosphorus (mg/kg) & --- & --- & --- & --- & $990.0 \pm 53.2$ & $903.0 \pm 48.7$ & $1176.2 \pm 61.7$ & $1102.3 \pm 57.7$ \\
\hline
\end{tabular}


Table 2: Results of analysis of variance examining the effect of year (2014-2016), season (spring, early summer, mid-summer, and fall), and grazing treatment (caged, uncaged) on environmental and plant characteristics at both wetland sites. One-way (belowground biomass [BGB]), two-way (soil total phosphorus [TP]), and three-way (\% organic matter [OM], total extractable inorganic nitrogen [TIN], total plant cover [TC], plant species richness $[\mathrm{S}]$, and Shannon Wiener diversity index $[\mathrm{H}])$ tests were used as appropriate. Significant $\mathrm{p}$-values are bolded $\left({ }^{*} \mathrm{p}<0.0001\right)$. $\mathrm{Yr}=$

\begin{tabular}{|c|c|c|c|c|c|c|c|c|c|c|c|c|c|c|}
\hline \multirow[t]{2}{*}{ Factor } & \multicolumn{2}{|c|}{ Year } & \multicolumn{2}{|c|}{ Season } & \multicolumn{2}{|c|}{ Treatment } & \multicolumn{2}{|c|}{ Yr x Seas } & \multicolumn{2}{|c|}{ Yr $\times \mathrm{Tr}$} & \multicolumn{2}{|c|}{ Seas $\times \mathrm{Tr}$} & \multicolumn{2}{|c|}{ Yr x Seas $\times$ Tr } \\
\hline & $F$ & $p$ & $\mathrm{~F}$ & $p$ & $\mathrm{~F}$ & $p$ & $\mathrm{~F}$ & $p$ & $\mathrm{~F}$ & $p$ & $\mathrm{~F}$ & $p$ & $F$ & $p$ \\
\hline \multicolumn{15}{|l|}{$A 1 N$} \\
\hline OM & $\begin{array}{c}F_{2,126}= \\
2.3\end{array}$ & 0.11 & $\begin{array}{c}F_{1,127}= \\
1.8\end{array}$ & 0.19 & $\begin{array}{c}F_{1,127}= \\
4.1\end{array}$ & 0.046 & $\begin{array}{c}F_{6,122}= \\
1.6\end{array}$ & 0.21 & $\begin{array}{c}F_{2,126}= \\
0.5\end{array}$ & 0.59 & $\begin{array}{c}F_{3,125}= \\
1.0\end{array}$ & 0.32 & $\begin{array}{c}F_{6,122}= \\
0.2\end{array}$ & 0.80 \\
\hline TIN & $\begin{array}{c}F_{2,110}= \\
4.0\end{array}$ & 0.021 & $\begin{array}{c}F_{1,111}= \\
38.4\end{array}$ & $<0.001^{*}$ & $\begin{array}{c}F_{1,111}= \\
3.0\end{array}$ & 0.09 & $\begin{array}{c}F_{6,106}= \\
14.3\end{array}$ & $<0.001^{*}$ & $\begin{array}{c}F_{2,110}= \\
0.6\end{array}$ & 0.55 & $\begin{array}{c}F_{3,109}= \\
3.4\end{array}$ & 0.07 & $\begin{array}{c}F_{6,106}= \\
1.2\end{array}$ & 0.30 \\
\hline TP & --- & --- & $\begin{array}{l}F_{1,63} \\
<0.1\end{array}$ & 0.90 & $\begin{array}{c}F_{1,63}= \\
0.4\end{array}$ & 0.53 & --- & --- & --- & --- & $\begin{array}{c}F_{1,63}= \\
3.1\end{array}$ & 0.08 & --- & --- \\
\hline $\mathrm{TC}$ & $\begin{array}{c}F_{2,350}= \\
6.1\end{array}$ & 0.002 & $\begin{array}{c}F_{3,349=} \\
128.2\end{array}$ & $<0.001^{*}$ & $\begin{array}{c}F_{1,351}= \\
79.8\end{array}$ & $<0.001^{*}$ & $\begin{array}{c}F_{6,356}= \\
19.5\end{array}$ & $<0.001^{*}$ & $\begin{array}{c}F_{2,350}= \\
14.7\end{array}$ & $<0.001^{\star}$ & $\begin{array}{c}F_{3,349}= \\
6.8\end{array}$ & $<0.001$ & $\begin{array}{c}F_{6,356}= \\
8.4\end{array}$ & $<0.001^{*}$ \\
\hline$S$ & $\begin{array}{c}F_{2,350}= \\
5.5\end{array}$ & 0.004 & $\begin{array}{c}F_{3,349}= \\
28.2\end{array}$ & $<0.001^{*}$ & $\begin{array}{c}F_{1,351}= \\
14.8\end{array}$ & $<0.001$ & $\begin{array}{c}F_{6,356}= \\
7.7\end{array}$ & $<0.001^{*}$ & $\begin{array}{c}F_{2,350}= \\
3.2\end{array}$ & 0.044 & $\begin{array}{c}F_{3,349}= \\
0.8\end{array}$ & 0.52 & $\begin{array}{c}F_{6,356}= \\
1.1\end{array}$ & 0.40 \\
\hline$H^{\prime}$ & $\begin{array}{c}F_{2,350}= \\
5.3\end{array}$ & 0.006 & $\begin{array}{c}F_{3,349}= \\
10.6\end{array}$ & $<0.001^{*}$ & $\begin{array}{c}F_{1,351}= \\
23.3\end{array}$ & $<0.001^{*}$ & $\begin{array}{c}F_{6,356}= \\
3.3\end{array}$ & 0.004 & $\begin{array}{c}F_{2,350}= \\
5.9\end{array}$ & 0.003 & $\begin{array}{c}F_{3,349=} \\
0.2\end{array}$ & 0.88 & $\begin{array}{c}F_{6,356}= \\
0.6\end{array}$ & 0.74 \\
\hline BGB & --- & --- & --- & --- & $\begin{array}{c}F_{1,31}= \\
6.0\end{array}$ & 0.021 & --- & --- & --- & --- & --- & --- & --- & --- \\
\hline \multicolumn{15}{|l|}{$A 3$} \\
\hline OM & $\begin{array}{c}F_{2,126}= \\
1.1\end{array}$ & 0.33 & $\begin{array}{c}F_{1,127}= \\
0.8\end{array}$ & 0.39 & $\begin{array}{c}F_{1,127}= \\
0.4\end{array}$ & 0.54 & $\begin{array}{l}F_{6,122} \\
<0.1\end{array}$ & 0.97 & $\begin{array}{l}\mathrm{F}_{2,126} \\
<0.1\end{array}$ & 0.98 & $\begin{array}{c}F_{3,125}= \\
0.5\end{array}$ & 0.49 & $\begin{array}{l}F_{6,122} \\
<0.1\end{array}$ & 0.97 \\
\hline TIN & $\begin{array}{c}F_{2,110}= \\
5.2\end{array}$ & 0.007 & $\begin{array}{c}\mathrm{F}_{1,111}= \\
25.6\end{array}$ & $<0.001^{*}$ & $\begin{array}{c}\mathrm{F}_{1,111}= \\
0.2\end{array}$ & 0.63 & $\begin{array}{c}\mathrm{F}_{6,106}= \\
11.4\end{array}$ & $<0.001^{*}$ & $\begin{array}{c}\mathrm{F}_{2,110}= \\
0.4\end{array}$ & 0.64 & $\begin{array}{l}\mathrm{F}_{3,109} \\
<0.1\end{array}$ & 0.97 & $\begin{array}{c}\mathrm{F}_{6,106}= \\
0.7\end{array}$ & 0.51 \\
\hline TP & --- & --- & $\begin{array}{c}F_{1,63}= \\
33.1\end{array}$ & $<0.001^{*}$ & $\begin{array}{c}F_{1,63}= \\
5.8\end{array}$ & 0.020 & --- & --- & --- & --- & $\begin{array}{l}\mathrm{F}_{1,63} \\
<0.1\end{array}$ & 0.85 & --- & --- \\
\hline $\mathrm{TC}$ & $\begin{array}{c}\mathrm{F}_{2,350}= \\
0.1\end{array}$ & 0.92 & $\begin{array}{c}F_{3,349=} \\
102.7\end{array}$ & $<0.001^{*}$ & $\begin{array}{c}F_{1,351}= \\
3.8\end{array}$ & 0.05 & $\begin{array}{c}F_{6,356}= \\
14.1\end{array}$ & $<0.001^{*}$ & $\begin{array}{l}\mathrm{F}_{2,350} \\
<0.1\end{array}$ & 0.99 & $\begin{array}{c}F_{3,349}= \\
0.6\end{array}$ & 0.61 & $\begin{array}{c}F_{6,356}= \\
0.6\end{array}$ & 0.70 \\
\hline$S$ & $\begin{array}{c}\mathrm{F}_{2,350}= \\
20.7\end{array}$ & $<0.001^{\star}$ & $\begin{array}{c}F_{3,349}= \\
18.3\end{array}$ & $<0.001^{*}$ & $\begin{array}{c}F_{1,351}= \\
9.6\end{array}$ & 0.002 & $\begin{array}{c}F_{6,356}= \\
7.2\end{array}$ & $<0.001^{*}$ & $\begin{array}{c}F_{2,350}= \\
4.4\end{array}$ & 0.013 & $\begin{array}{c}F_{3,349=} \\
0.9\end{array}$ & 0.42 & $\begin{array}{c}F_{6,356}= \\
1.0\end{array}$ & 0.42 \\
\hline$H^{\prime}$ & $\begin{array}{c}F_{2,350}= \\
2.5\end{array}$ & 0.09 & $\begin{array}{c}F_{3,349}= \\
6.4\end{array}$ & $<0.001$ & $\begin{array}{c}F_{1,351}= \\
17.3\end{array}$ & $<0.001^{*}$ & $\begin{array}{c}F_{6,356}= \\
2.0\end{array}$ & 0.07 & $\begin{array}{c}F_{2,350}= \\
5.9\end{array}$ & 0.003 & $\begin{array}{c}F_{3,349}= \\
1.1\end{array}$ & 0.37 & $\begin{array}{c}F_{6,356}= \\
0.8\end{array}$ & 0.55 \\
\hline INV & $\begin{array}{c}F_{2,350}= \\
5.2\end{array}$ & 0.006 & $\begin{array}{c}F_{3,349}= \\
10.4\end{array}$ & $<0.001^{*}$ & $\begin{array}{c}F_{1,351}= \\
3.3\end{array}$ & 0.07 & $\begin{array}{c}F_{6,356}= \\
1.0\end{array}$ & 0.41 & $\begin{array}{c}F_{2,350}= \\
0.1\end{array}$ & 0.91 & $\begin{array}{c}F_{3,349}= \\
1.6\end{array}$ & 0.20 & $\begin{array}{c}F_{6,356}= \\
1.1\end{array}$ & 0.39 \\
\hline BGB & --- & --- & --- & --- & $\begin{array}{l}F_{1,31} \\
<0.1 \\
\end{array}$ & 0.84 & --- & --- & --- & --- & --- & --- & --- & --- \\
\hline
\end{tabular}




\section{Funding Sources:}

The authors gratefully acknowledge Waste Management of New York and the Thomas $\mathrm{H}$. Gosnell School of Life Sciences and the College of Science at the Rochester Institute of Technology for supporting this work 
Table S1: Soil and plant characteristics in uncaged control plots (mean \pm SE) and results of oneway analysis of variance comparing sites. Significant $p$-values are bolded and * indicates $p$ $<0.0001$.

\begin{tabular}{|c|c|c|c|c|}
\hline & A1N & A3 & $\mathbf{F}$ & $p$ \\
\hline Organic matter (OM, \%) & $7.5 \pm 0.4$ & $13.4 \pm 0.5$ & $F_{1,111}=87.8$ & $<0.001^{*}$ \\
\hline Total inorganic nitrogen (TIN, mg/kg) & $6.2 \pm 1.8$ & $17.1 \pm 3.4$ & $F_{1,111}=17.1$ & $<0.001^{*}$ \\
\hline Total phosphorus (TP, $\mathrm{mg} / \mathrm{kg}$ ) & $704.3 \pm 28.0$ & $1002.7 \pm 53.2$ & $F_{1,63}=42.6$ & $<0.001^{*}$ \\
\hline Total plant cover (TC, \%) & $48.4 \pm 5.5$ & $55.1 \pm 6.4$ & $F_{1,351}=2.5$ & 0.11 \\
\hline Species richness $(S)$ & $2.2 \pm 0.3$ & $3.9 \pm 0.5$ & $F_{1,351}=73.3$ & $<0.001^{*}$ \\
\hline Shannon-Weiner $\left(H^{\prime}\right)$ & $0.4 \pm 0.1$ & $0.9 \pm 0.1$ & $F_{1,351}=74.4$ & $<0.001^{*}$ \\
\hline Belowground biomass (BGB, $\mathrm{g} / \mathrm{m}^{2}$ ) & $19.2 \pm 1.9$ & $21.8 \pm 3.5$ & $F_{1,31}=0.4$ & 0.51 \\
\hline
\end{tabular}




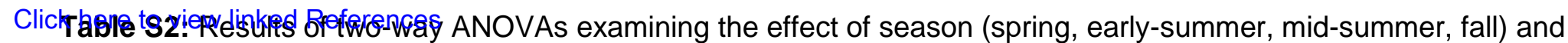
grazing treatment (caged/uncaged) on stem height (cm), stem density, and cover (\%) for major plant species in Area 1 North. Minor species not analyzed: Asclepias incarnate, Carex spp., Epilobium spp., Juncus effuses, Lythrum salicaria ${ }^{\star *}$, Nymphaea odorata, Sparganium americanum, Typha spp. ${ }^{* *}$ Significant $\mathrm{p}$-values are bolded $\left({ }^{*} \mathrm{p}<0.0001\right.$; ${ }^{*}$ invasive species). $\mathrm{C}=$ caged plots, $\mathrm{U}=$ uncaged control plots, Seas= season, $\mathrm{Tr}=$ treatment

\begin{tabular}{|c|c|c|c|c|c|c|c|c|}
\hline \multirow{2}{*}{ Factor } & \multicolumn{2}{|c|}{ Avg \pm SE } & \multicolumn{2}{|c|}{ Season } & \multicolumn{2}{|c|}{ Treatment } & \multicolumn{2}{|c|}{ Seas $\times \mathrm{Tr}$} \\
\hline & $\mathrm{C}$ & U & $F_{3,125}$ & $p$ & $\mathrm{~F}_{1,127}$ & $p$ & $F_{3,125}$ & $p$ \\
\hline Height & $19.6 \pm 3.1$ & $9.6 \pm 1.7$ & 15.98 & $<0.001^{*}$ & 11.82 & $<0.001$ & 6.32 & $<0.001$ \\
\hline Density & $5.0 \pm 1.0$ & $2.6 \pm 0.6$ & 3.30 & 0.023 & 4.58 & 0.034 & 1.04 & 0.376 \\
\hline $\begin{array}{l}\text { Cover } \\
\text { L. oryzoides }\end{array}$ & $4.6 \pm 1.1$ & $1.2 \pm 0.2$ & 4.75 & 0.004 & 10.22 & 0.002 & 2.57 & 0.058 \\
\hline Height & $14.2 \pm 4.1$ & $7.8 \pm 3.2$ & 4.75 & 0.004 & 1.54 & 0.216 & 0.40 & 0.752 \\
\hline Dens & $4 \pm 1.6$ & $0.3 \pm 0.1$ & 1.15 & 0.33 & 6.58 & 0.012 & 0.87 & 0.459 \\
\hline $\begin{array}{l}\text { Cover } \\
\text { Polygonum spp. }\end{array}$ & $3.5 \pm 1.6$ & $0.2 \pm 0$ & 1.18 & 0.322 & 4.53 & 0.036 & 0.82 & 0.485 \\
\hline $\begin{array}{l}\text { Height } \\
\text { Density }\end{array}$ & $\begin{array}{l}62.3 \pm 5.4 \\
21.0 \pm 2.2\end{array}$ & $\begin{array}{c}18.1 \pm 3.0 \\
3.5 \pm 0.8\end{array}$ & $\begin{array}{c}84.25 \\
6.44\end{array}$ & $\begin{array}{l}<0.001^{*} \\
<0.001\end{array}$ & $\begin{array}{c}185.62 \\
68.53\end{array}$ & $\begin{array}{l}<0.001^{*} \\
<0.001^{*}\end{array}$ & $\begin{array}{c}24.39 \\
2.10\end{array}$ & $\underset{*}{<.001}$ \\
\hline Cover & $21.9 \pm 2.6$ & $2.6 \pm 0.6$ & 18.84 & $<0.001^{*}$ & 89.19 & $<0.001^{*}$ & 13.60 & $\begin{array}{c}0.104 \\
<0.001 \\
*\end{array}$ \\
\hline P. corda & & & & & & & & \\
\hline Hei & $7.8 \pm 3.2$ & $8.3 \pm 2.8$ & 1.85 & 0.142 & 0.01 & 0.915 & 0.18 & 0.908 \\
\hline Den & $1.0 \pm 0.4$ & $1.7 \pm 0.6$ & 0.93 & 0.429 & 0.98 & 0.324 & 0.07 & 0.979 \\
\hline $\begin{array}{l}\text { Cover } \\
\text { P. amplifolius }\end{array}$ & $1.1 \pm 0.5$ & $2.9 \pm 1.5$ & 0.88 & 0.456 & 1.28 & 0.260 & 0.38 & 0.770 \\
\hline Heigl & $0.5 \pm 0.3$ & $1.9 \pm 0.7$ & 4.37 & 0.00 & 4.28 & 0.0 & 2.22 & 0.089 \\
\hline Den & $3 \pm 0.8$ & $2.0 \pm 0$. & 2.90 & 0.03 & 0.47 & 0.4 & 0.34 & 0.797 \\
\hline $\begin{array}{l}\text { Cover } \\
\text { S. latifolia }\end{array}$ & $1.7 \pm 1.0$ & $1.4 \pm 0.5$ & 1.33 & 0.269 & 0.08 & 0.780 & 0.02 & 0.996 \\
\hline Height & $3.1 \pm 6.1$ & $60.1 \pm 5$ & 256.1 & $<0.001^{\star}$ & 18.84 & $<0.001^{*}$ & 2.44 & 0.068 \\
\hline Den & $7.0 \pm 1.8$ & $12.8 \pm 1$. & 3 & $<0.0$ & 9.20 & & 1.36 & 0.258 \\
\hline Cover & $44.1 \pm 4.6$ & $29.9 \pm 3.6$ & $\begin{array}{l}56.62 \\
74.68\end{array}$ & $<0.001^{*}$ & 16.27 & $<0.001^{*}$ & 2.95 & 0.036 \\
\hline & & & & & & & & \\
\hline & & $2.9 \pm 2$ & 1.01 & & 1.62 & 0.2 & 0.12 & 0.948 \\
\hline Deı & $1 \pm 0.6$ & $0.2 \pm 0$ & 0.27 & 0.8 & 2.15 & 0.1 & 0.29 & 0.835 \\
\hline Cover & $0.8 \pm 0.5$ & $0.1 \pm 0.0$ & 0.81 & 0.809 & 2.72 & 0.102 & 0.45 & 0.720 \\
\hline
\end{tabular}


